\title{
Fostering land use sustainability through construction land reduction in China: an analysis of key success factors using Fuzzy-AHP and DEMATEL
}

\section{Qiang Li (D810644528@qq.com)}

Northwestern Polytechnical University School of Management https://orcid.org/0000-0002-0445-7687

\section{Lifang Wang}

Northwestern Polytechnical University

Yuming Zhu

Northwestern Polytechnical University

\section{Bingxu Mu}

Northwestern Polytechnical University

Naveed Ahmad

Northwestern Polytechnical University

\section{Research Article}

Keywords: Construction land reduction,Key success factors, Fuzzy-AHP, Fuzzy-DEMATEL

Posted Date: March 29th, 2021

DOl: https://doi.org/10.21203/rs.3.rs-202001/v1

License: (c) (1) This work is licensed under a Creative Commons Attribution 4.0 International License. Read Full License

Version of Record: A version of this preprint was published at Environmental Science and Pollution Research on October 26th, 2021. See the published version at https://doi.org/10.1007/s11356-02115845-8. 


\title{
Fostering land use sustainability through construction land reduction in China: an analysis of key success factors using Fuzzy-AHP and DEMATEL
}

\author{
Qiang $\mathrm{Li}^{1} \quad$ Lifang Wang $^{1} \quad$ Yuming Zhu ${ }^{1} \quad$ Bingxu Mu $\mathrm{Mu}^{1} \quad$ Naveed Ahmad $^{1}$ \\ ${ }^{1}$ School of Management, Northwestern Polytechnical University, Xi'an, 710072, China \\ failureend@163.com,lifang@nwpu.edu.cn,zym1886@nwpu.edu.cn, \\ bingxu0908@mail.nwpu.edu.cn,naveedahmad@mail.nwpu.edu.cn
}

corresponding author:Qiang Li ${ }^{1}$, failureend@163.com.

\begin{abstract}
Construction land reduction (CLR) is an important instrument for achieving environmental sustainability by reducing intensive land use, controlling the unrestrained extension of construction land and ensuring a balance between construction and arable lands in China. Existing studies on key factors of CLR projects are rare, lacking comprehensive and systematic understanding. Key factors for ensuring the success of CLR projects have not been identified in previous studies. Based on a literature review and questionnaires, in this study, key success factors (KSFs) of CLR projects were identified and analysed. The Fuzzy-AHP and Fuzzy-DEMATEL methods were used to obtain the comprehensive causality and centrality values, whereby factors with a comprehensive causality value larger than 0 and a comprehensive centrality ranking in the top 20\% were identified as KSFs. Results indicate that KSFs include the presence of a supportive policy for CLR, coordination with the original landowner, coordination with the surrounding residents, a diversity of enterprises participating in the CLR, a legal environment and land acceptance and testing standards. This paper lays a theoretical foundation for CLR projects and provides guidelines for achieving successful project implementations.
\end{abstract}

Keywords: Construction land reduction,Key success factors, Fuzzy-AHP, Fuzzy-DEMATEL 1. Introduction

Since the new millennium, China has experienced a gradual increase in the rate of urbanization. According to Chinese Government Work Report, from 2000 to 2020, the urbanization rate has been increased from $36.2 \%$ to $60.34 \%$, with an annual growth of $2.41 \%$ and China has faced huge pressure due to rapid urban development. With the acceleration of urbanization in China, the demand for construction land has also been increased. On one hand, the urban dependence on new construction land has resulted in decreases in the amount of arable land and impacts negatively on the ecological environment. On the other hand, this dependence has been associated with the disorganized extension of construction land, resulting in extremely low land-utilization efficiency. In April 2016, the Ministry of Land and Resources of the People's Republic of China issued Guidelines for the $13^{h}$ Five-Year Plan for Land and Resources, which proposed to decrease the total area of construction land, perform an inventory of construction land and consider construction land reduction as a national strategy. Given this background, China implemented a comprehensive integration and scientific distribution of the construction land inventory to relieve the conflict between the demand for fast growth and required construction land Also, there is a huge concentration on mantaining inventories overcome the low efficiency of construction land. CLR is 
an important instrument for achieving sustainable development via improvements in intensive land use, controlling the unrestrained extension of construction land, and ensuring a requisitioncompensation balance between construction and arable lands in China. How to use construction land effectively is a huge dilemma in developing economies and a complex process, that is influenced by many factors. A crucial aspect of this process is the determination of key success factors (KSFs). Today, the major problem of CLR is the lack of an established scientific and effective method for its achievement. Because studies in China and around the world have mainly focused on land redevelopment(Zhu Yuming, Tao, YU Ming-Jie), to address this research gap, this study proposed a method for identifying KSFs of CLR projects.

KSF is one of the common methods of Information System Development planning, It was proposed by Harvard Professor William Zani in 1970, John F.Rockart (1979). In the operation and management of a company or organization, if an enterprise can occupy an advantage in a few key areas, it can ensure its strong competitiveness in the market. Only by controlling the key points and key areas, and seriously treating these key factors, the enterprise can maintain good performance. Leidecker and Bruno (1984) indicated that KSFs are some characteristics, conditions, or variables in which an enterprise has a significant impact on market competition, need to appropriate and constant attention and management. KSFs are closely related to core competency building, It can reveal the major and universal elements and capabilities in the development of an industry or enterprise. The theoretical roots of the KSFs is to follow the Pareto principle (Wang\& Zhang ). That is, those with a key role are the minority, and those with a secondary role are the majority.

Considering the above-mentioned discussion, the purpose of this paper is to create a complete set of influencing factors based on the success of CLR projects. If KSFs can be identified during implementation, considerable effort and costs can be saved and the utilization rate of labor and/or costs can be greatly improved. As such, it will be extremely effective to implement the land reduction project.

To achieve study objective, a set of KSFs in CLR projects was created based on an analysis of the current construction land literature. Then, this set of influencing factors was enriched by interviews with experts from relevant enterprises. Next, the opinions of these experts were analyzed to identify a set of factors that influence service innovation. Lastly, the study results were analyzed and the contribution and significance of this study were discussed. This paper is innovative in its combination of theoretical research with real-world conditions and the classification of KSFs into subject reduction, element reduction, system reduction, and the environment. Each KSF was subdivided into many second-level influencing factors of construction land reduction projects.

\section{Theoretical background}

"Reduction" is an important concept in the field of solid waste management, generally refers to the reduction of resource consumption and waste generation in production, circulation, and consumption. It is widely used in the field of the circular economy. CLR is also known as land reduction, it means demolishing or reclaiming construction land that does not meet the requirements of the general plan for land use which has poor social, economic, or environmental benefits and low development efficiency. It ensures the restoration of the land for the agricultural production and 
promotes ecological benefits of construction lands. In the area of land resource management, reducing the occupation of construction land involves reducing the consumption of new land resources, and increase the utilization intensity of the original construction land resources. The essence of it is to reduce intensive land use, that is Land use efficiency.

Minister of Land and Resources of China Shaoqin Zhuang (2015) regarded the construction land reduction as the key point of land incremental management.In view of the current situation of land use and its resource conditions in Shanghai, a strategy of "five-volume control" is put forward, which includes "total volume lock, increment decrease, stock optimization, quality improvement and flow efficiency increase". The land is the basis for the coordinated development of social economy, population, and natural factors. Scientific overall planning of land resources can promote the harmonious and stable development of society. As one of the ways of land resource management, construction land reduction plays an important role.

At present, the research of the CLR in China mainly focuses on the following three aspects: Concept definition and connotation: Xiaokun $\mathrm{Gu}$ (2018) pointed out that the construction land reduction is similar to "Brownfield Redevelopment" .It is the only way to realize sustainable development, practice the "green development concept" and build a "green city".Yuanqing Wu (2015) pointed out that the CLR refers to the removal and reclamation of the existing construction land which is scattered, abandoned, damaged, idle and inefficient outside the built-up area, so as to reduce the amount of inefficient construction land. Hongmei Liu (2015) found that the CLR is similar to the connotation of "reclamation" or "renovation", but more emphasis is placed on the land used for construction purposes and land shall be returned in the environmentally friendly position, and to achieve the goal of reducing the total amount of construction land. It is an innovative attempt to land management policy. CLR involves two aspects: one is to save and reduce consumption, reduce the demand for new construction land resources, and control the growth of construction land. Another is to reduce inventory and increase efficiency. By compressing and reduce the existing construction land scale, improve the construction land-use intensity, to achieve the target of an intensive increase in efficiency. The connotation includes the following aspects:(1) CLR is the result of economic development to a certain level. Only when the economic growth reaches a certain level and the dependence on the input of construction land is reduced, the CLR can be implemented. (2) CLR means that after the economic growth reaches a certain level, the increment of construction land gradually decreases, and the economic growth mainly depends on the stock of construction land. (3) CLR is based on the reduction of regional land carrying capacity, In order to limit the urban extension development.

Structural operation mechanism: Xu Guo (2020) analyzed the essence and operation logic of CLR in theory. In practice, the progress, characteristics, and modes of reducing governance are summarized. An analytical framework of "corporatism - control rights - reconstruction of land interests" is proposed which analyzes the land benefit reconstruction of multiple subjects in the process of land reduction. Juying Yan (2019) introduced the smart contraction theory which studies the operation mechanism of CLR in Hongze District and puts forward the direction and strategy of optimization. This study points out that although the construction land space is expanding, the space utilization efficiency is improved and the land intensification has achieved initial results. However, 
the change of smart contraction trend fluctuates, indicating that the control of reduction promotion is more unstable and there are many influencing factors, such as Farmers' activities decreased, Expansion of construction land area.

Policy optimization: Xiaojie Zhang (2015) studied the policy implementation of construction land in Tianjin, also analyzes the implementation mechanism of construction land reduction in Tianjin. Suggestions are put forward, such as establishing the multi-department linkage working mechanism, perfecting the government assessment mechanism and perfecting other supporting measures. Shoubo Gu (2015) summarized the relevant policies and specific requirements of Shanghai municipality on promoting the reduction of "198" regional construction land. The study points out that multi-sectoral policy synergy, focus on the use of funds, and strengthen comprehensive law enforcement are the need of era to facilitate CLR. To study and formulate the performance evaluation system of CLR, the remediation and treatment of soil after the removal of pollutants. It is pointed out that we should explore the financing channels of comprehensive land improvement to break the capital bottleneck.

In conclusion, the research on the CLR is mainly reflected in the concept, connotation, and structure operation mechanism, as well as how to improve the utilization efficiency of construction land. However, there is a lack of comprehensive and systematic research on the factors affecting the CLR. More importantly, most of these studies are qualitative, but very few of them use quantitative methods to systematically analyze the key factors and their interrelationships. Therefore, from the perspective of project management, this study will comprehensively and systematically explore the factors of the CLR by combining qualitative and quantitative methods to identify KSFs. To put forward, opinions and suggestions from the experts' by utilizing a mix off qualitative and quantitative methodologies will support in decision making of China's land use planning.

\section{Proposed framework to identify KSFs of CLR}

This study proposed a framework comprised of Delphi, FAHP, and DEMATEL to identify the KSFs of CLR project in China (Fig 1). In the first stage, Fuzzy Delphi method is used to identify the KSFs of CLR from literature. In the second stage, consensus KSFs for CLR are put forward by experts. In the third stage, the weights of success factors are assessed using the FAHP method, Fuzzy-DEMATEL method is used to better reflect the fuzziness of the relationship between factors in the system, so that KSFs can be identified accurately and directly. 
1. Identification of KSFs from literature

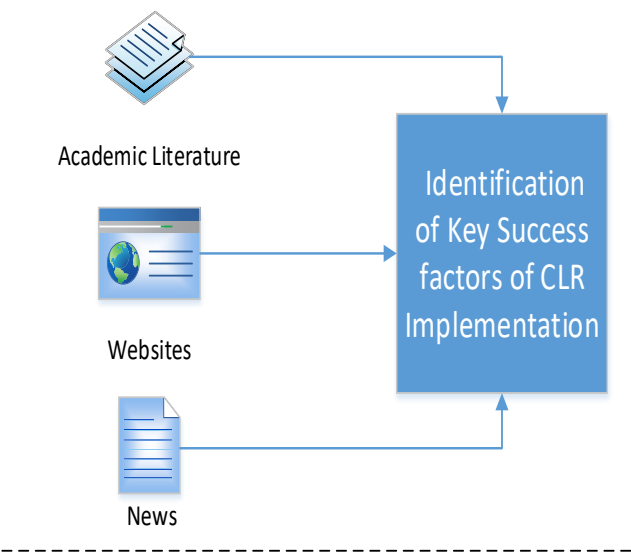

3. Evaluation of cause and effect relationship

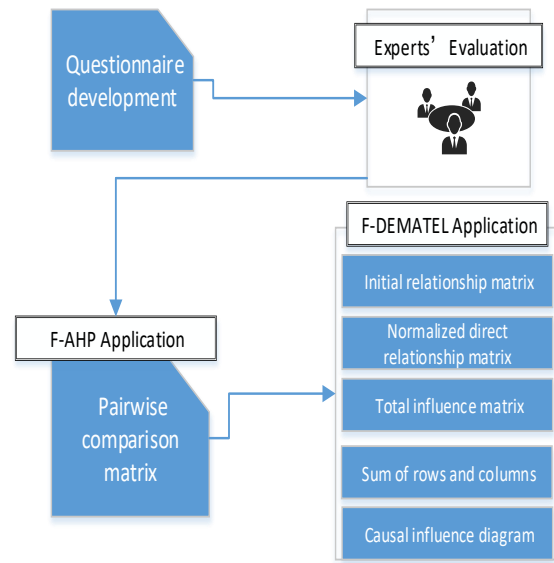

2. Consensus on KSFs by experts
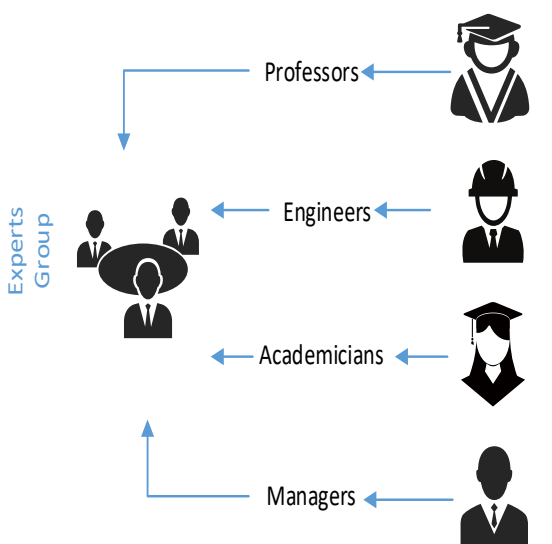

4. Validation of results

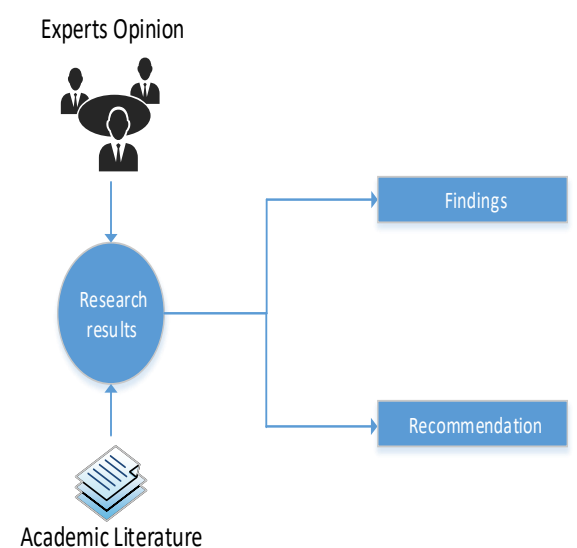

Figure1 Proposed framework of study

\subsection{Identification of KSFs from literature}

The index data of this paper was mainly derived from two sources. The first source is the information related to the different themes of CLR published on the website of the Chinese government platform or enterprise website. The other is the document information of periodicals, newspapers, and other documents related to the theme of "construction land" collected by CNKI (China National Knowledge Infrastructure) and Web of Science.

System theory was founded by L.V. Bertalanffy, an Austrian American theoretical biologist. In 1948, when he taught "General Systems theory" in the United States, his theory began to won academic attention. The word 'system' means the whole made up of parts. General systems theory tries to give a definition that describes the characteristics of various systems, a 'system' is usually defined as an organic whole with a certain function composed of several elements connected in a certain structural form (Yi Ding). The basic philosophy of 'system theory' is to take the object studied and dealt with it as a system, analyze the structure and function of the system, to study the relationship among 'Principal part of system' 'Key elements' and 'Environment'. Everything in the world can be seen as a system, the system is universal. Therefore, this paper regards the CLR as a system, to identify the KSFs from 'Principal part of CLR 'Key element of 
CLR' and 'environment of CLR' .

For the acquisition of KSFs on CLR, this paper took 'land for construction' 'Rural land' and 'Urban Construction land' as keywords respectively in the literature search part. Relevant literature from 2010 to June 2020 was selected, a total of 262 publsihed studies in Chinese language and 186 papers were selected in the English language. Through literature review and screening, a total of 57 references with high relevance to this study were counted. The relevant influencing factors of the CLR are counted and classified with reference to the analysis writing above.

\subsection{Consensus on KSFs by experts}

Chinese land experts, scholars, and enterprise managers and engineers were invited for special interviews. Based on the practical investigation in Shanghai, the final set of initial relevant influencing factors was determined, and 29 influence factors were obtained.(see Tab. 1)

Table 1 Initial key success factors for construction land reduction

\begin{tabular}{|c|c|c|c|c|}
\hline & \multicolumn{2}{|c|}{ Influence factors } & Explanation & References \\
\hline \multirow{7}{*}{$\begin{array}{l}\text { Key success } \\
\text { factors of } \\
\text { construction } \\
\text { land reduction }\end{array}$} & \multirow{7}{*}{$\begin{array}{l}\text { Principal part of } \\
\text { construction land } \\
\text { reduction } \\
\text { A }\end{array}$} & $\begin{array}{l}\text { Development plans } \\
\text { for the construction } \\
\text { land reduction } \\
\text { project }\end{array}$ & $\begin{array}{l}\text { The government formulates } \\
\text { development plans for the } \\
\text { construction land reduction } \\
\text { project. }\end{array}$ & $\begin{array}{l}\text { Hai Jiang, Tu Lv (2016); } \\
\text { Xiaokun Gu,Jing Liu } \\
\text { (2018); Juan Huang } \\
\text { (2020) }\end{array}$ \\
\hline & & $\begin{array}{l}\text { Management system } \\
\text { of the construction } \\
\text { land reduction } \\
\text { project }\end{array}$ & $\begin{array}{l}\text { The government establishes } \\
\text { and gradually improves the } \\
\text { management system, working } \\
\text { mode, evaluation method, and } \\
\text { motivation mechanism used in } \\
\text { the construction land reduction } \\
\text { project. }\end{array}$ & $\begin{array}{l}\text { Shoubo Gu, Wei Liu } \\
\text { (2016) }\end{array}$ \\
\hline & & $\begin{array}{l}\text { Coordination } \\
\text { organization of the } \\
\text { construction land } \\
\text { reduction project }\end{array}$ & $\begin{array}{l}\text { The government sets up a } \\
\text { planning and coordination } \\
\text { organization for the } \\
\text { construction land reduction } \\
\text { project. }\end{array}$ & $\begin{array}{l}\text { Shuang Li,Jiang Lou } \\
\text { (2016) }\end{array}$ \\
\hline & & $\begin{array}{l}\text { Administrative } \\
\text { supervision and } \\
\text { management level }\end{array}$ & $\begin{array}{l}\text { The legal sector supervises the } \\
\text { workflow and quality of the } \\
\text { construction land reduction } \\
\text { project. }\end{array}$ & $\begin{array}{c}\text { Shoubo Gu,Wei Liu } \\
\text { (2016);Shuang Li,Jiang } \\
\text { Lou (2016) }\end{array}$ \\
\hline & & $\begin{array}{l}\text { Qualification and } \\
\text { certification process }\end{array}$ & $\begin{array}{l}\text { Only a third-party enterprise } \\
\text { can apply for land qualification } \\
\text { and certification. }\end{array}$ & Yu He (2019) \\
\hline & & $\begin{array}{c}\text { Diversity of } \\
\text { enterprises } \\
\text { participating in the } \\
\text { construction land } \\
\text { reduction project }\end{array}$ & $\begin{array}{l}\text { A diverse range of enterprises } \\
\text { participate in the construction } \\
\text { land reduction project (sound } \\
\text { market competition). }\end{array}$ & Yu He (2019) \\
\hline & & $\begin{array}{l}\text { Enterprise capacity } \\
\text { and competence }\end{array}$ & $\begin{array}{l}\text { Scale, management capacity, } \\
\text { technical capacity, and capital }\end{array}$ & Yu He (2019) \\
\hline
\end{tabular}




\begin{tabular}{|c|c|c|c|}
\hline & & $\begin{array}{l}\text { of an enterprise participating in } \\
\text { the construction land reduction } \\
\text { project. }\end{array}$ & \\
\hline & $\begin{array}{c}\text { Enterprise rules and } \\
\text { regulations }\end{array}$ & $\begin{array}{l}\text { Rules and regulations of an } \\
\text { enterprise participating in the } \\
\text { construction land reduction } \\
\text { project. }\end{array}$ & Yu He (2019) \\
\hline & $\begin{array}{l}\text { Coordination with } \\
\text { original landowner }\end{array}$ & $\begin{array}{c}\text { Policy awareness, } \\
\text { understanding of, and } \\
\text { coordination with original } \\
\text { landowner in the construction } \\
\text { land reduction project. }\end{array}$ & Yu He (2019) \\
\hline & $\begin{array}{l}\text { Coordination with } \\
\text { surrounding } \\
\text { residents }\end{array}$ & $\begin{array}{c}\text { Policy awareness, } \\
\text { understanding of, and } \\
\text { coordination with surrounding } \\
\text { residents in the construction } \\
\text { land reduction project. }\end{array}$ & $\begin{array}{l}\text { Shoubo Gu,Wei Liu } \\
\text { (2016) }\end{array}$ \\
\hline & $\begin{array}{l}\text { Advance payments } \\
\text { for land reclamation }\end{array}$ & $\begin{array}{l}\text { Advance payments from town } \\
\text { and district governments for } \\
\text { the construction land reduction } \\
\text { project. }\end{array}$ & $\begin{array}{c}\text { Shoubo Gu,Wei Liu } \\
\text { (2016);Chi Zhang (2019) }\end{array}$ \\
\hline & $\begin{array}{c}\text { Status of } \\
\text { construction } \\
\text { organization for land } \\
\text { remediation and } \\
\text { reclamation }\end{array}$ & $\begin{array}{l}\text { Technical level and capital } \\
\text { progress of the construction } \\
\text { organization. }\end{array}$ & Yu He (2019) \\
\hline \multirow{4}{*}{$\begin{array}{l}\text { Key element of } \\
\text { construction land } \\
\text { reduction project } \\
\text { B }\end{array}$} & $\begin{array}{l}\text { Standards for land } \\
\text { acceptance and } \\
\text { testing }\end{array}$ & $\begin{array}{l}\text { Improved and consistent land } \\
\text { acceptance and testing } \\
\text { standards after reduction. }\end{array}$ & $\begin{array}{l}\text { Xiaokun Gu,Jing Liu } \\
\text { (2018) }\end{array}$ \\
\hline & $\begin{array}{l}\text { Maturity of related } \\
\text { technologies }\end{array}$ & $\begin{array}{l}\text { Maturity and innovation of } \\
\text { applied land-reduction-related } \\
\text { technologies (e.g., testing } \\
\text { technology, reclamation } \\
\text { technology). }\end{array}$ & Hai Jiang,Tu Lv (2016) \\
\hline & $\begin{array}{l}\text { Diversity of } \\
\text { historical data }\end{array}$ & $\begin{array}{l}\text { Diverse range of historical data } \\
\text { obtained regarding the } \\
\text { influences of the surrounding } \\
\text { environment of historical } \\
\text { enterprises. }\end{array}$ & Added by experts \\
\hline & $\begin{array}{l}\text { Scientific land } \\
\text { reduction process }\end{array}$ & $\begin{array}{l}\text { Scientific and operational } \\
\text { processes used in the } \\
\text { construction land reduction } \\
\text { project formulated by the } \\
\text { government and related }\end{array}$ & $\begin{array}{c}\text { Ming } \\
\text { Chen(2017);Xiaokun } \\
\text { Gu,Jing Liu (2018) }\end{array}$ \\
\hline
\end{tabular}




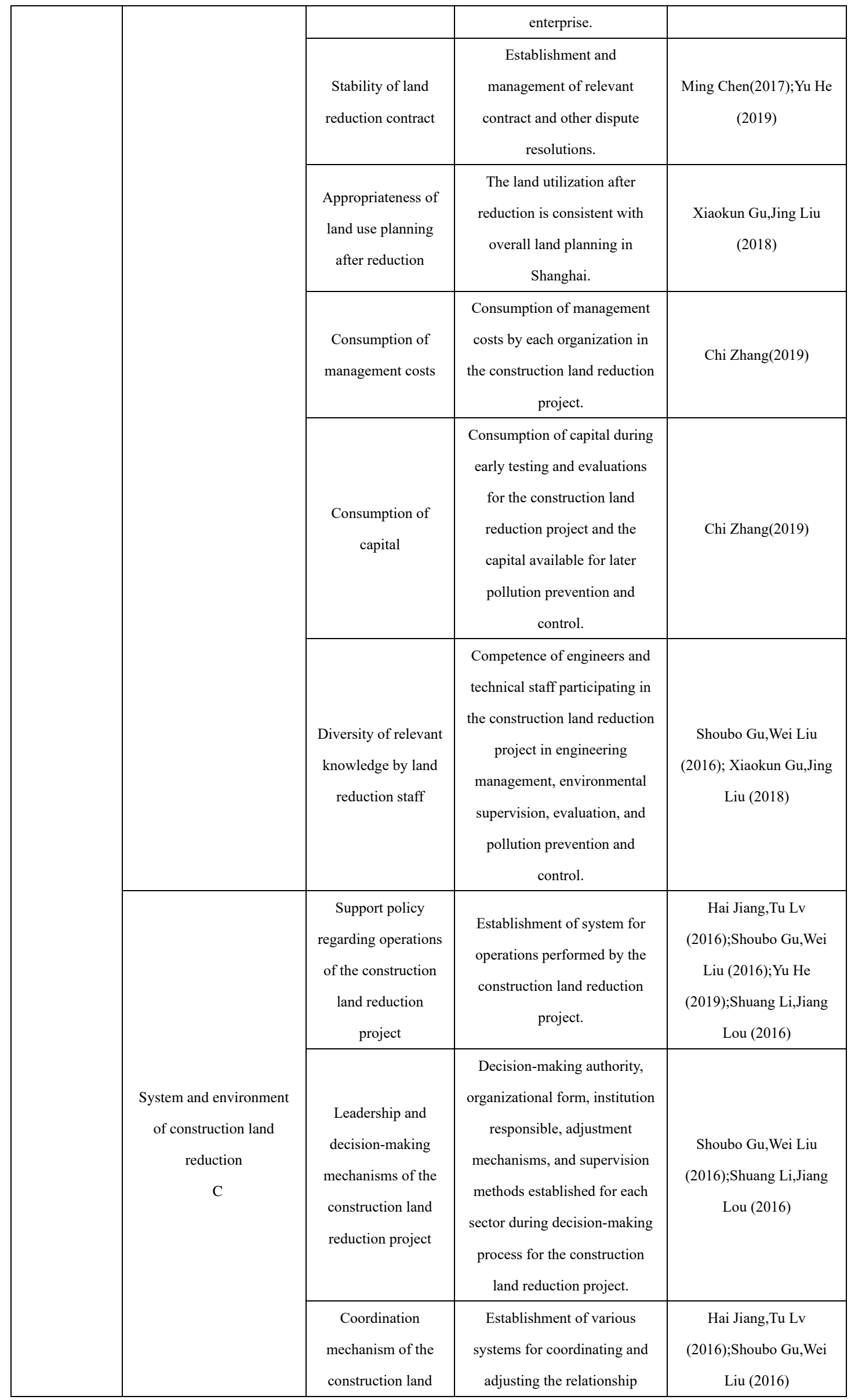




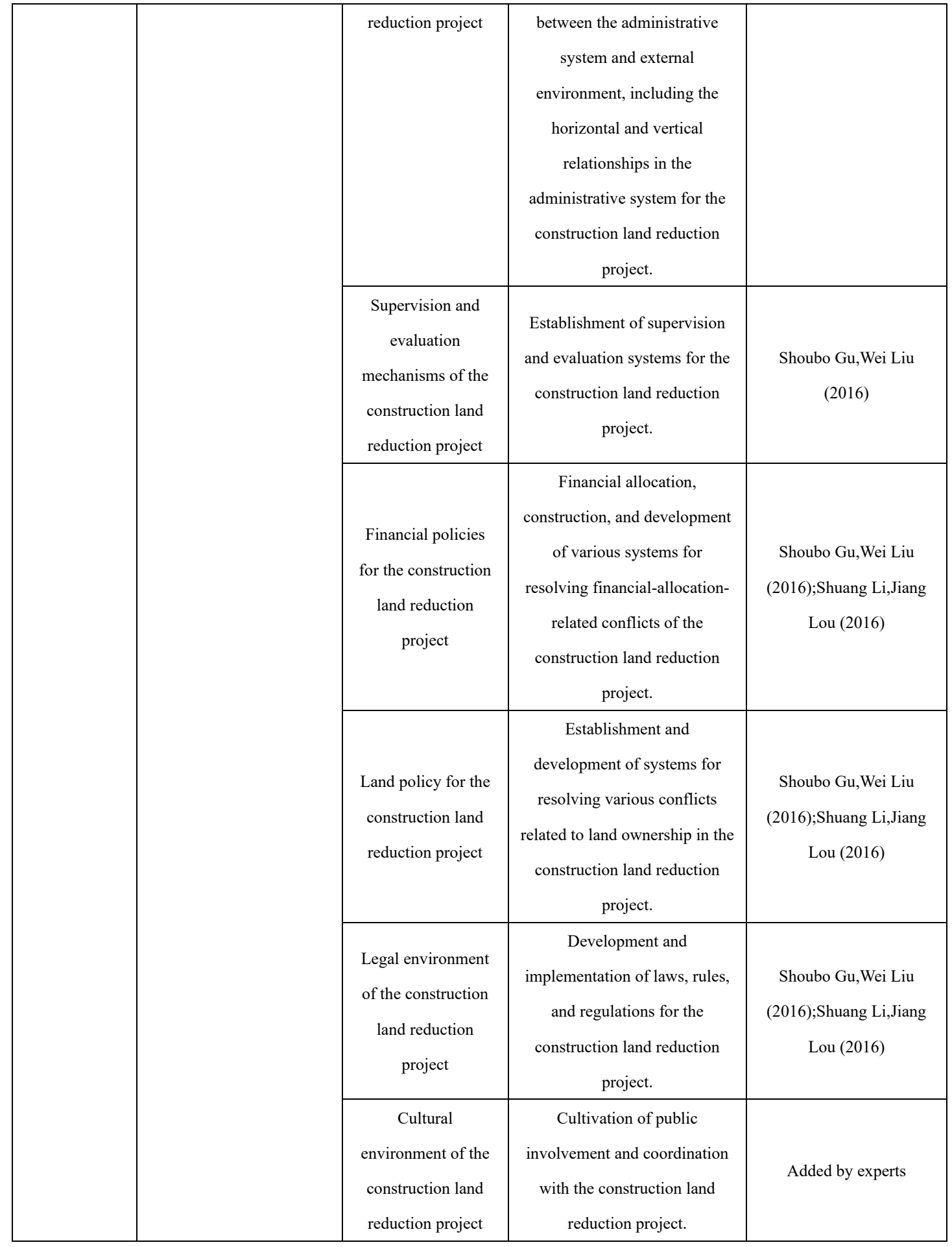

\section{Evaluation of cause and effect relationship}

There are multiple methods to identify KSFs in the previous research, such as customer and management interviews, expert opinion, literature research, case analysis, etc. And the tools for identifying factors are also various, such as fishbone diagram, Interpretative structural model (ISM), Analytic hierarchy process, etc. In this paper, Fuzzy Analytic hierarchy process (FAHP) and FuzzyDEMATEL (Decision Making Trial and Evaluation Laboratory) are combined to construct a model for KSFs of CLR. In this model, the Fuzzy-DEMATEL method is used to prioritize the factors following their influence on the system. At the same time, combined with the factor weight 
determined by the FAHP method, the key success factors of CLR are finally identified. The advantages of mixed methodology of FAHP and DEMATEL are as follow:

(1) The integrated methodology combining fuzzy theory with traditional AHP and DEMATEL is more advantageous where the absolute value 0 or 1 is replaced by a corresponding membership function in the subjective judgment data, which is more scientific as it reflects the fuzziness of human being's subjective judgment.

(2) Although the KSFs can be identified on the basis of the factor weight determined by the traditional AHP method, the relationships between the factors and their attribute status in the system cannot be analyzed.

(3) By combining the factor weight data determined by FAHP with the influence degree data of factors in the system obtained by Fuzzy-DEMATEL method, more information can be integrated, making the conclusions more reliable.

\subsection{Weights calculation of influencing factors based on FAHP method}

\subsubsection{Calculation process of FAHP method}

The analytic hierarchy process (AHP) is a systematic method that regards a complex multiobjective decision-making (MODM) problem as a system. By decomposing the goals into multiple objectives or criteria and several levels of multi-index, it can provide multi-scheme optimization decisions in accordance with both hierarchical single ranking and total ranking. Because of its systematic, concise, flexible, and practical features, AHP can effectively measure the judgment and comparison of decision-makers and is widely used in various fields. However, it also has some obvious disadvantages, such as:

1. The membership degree in the judgment matrix can only be 0 or 1 , which is too absolute to reflect the fuzziness of experts' subjective judgment.

2. It is rather difficult to check the consistency of the judgment matrix which needs to be adjusted and tested repeatedly and blindly.

3. Taking CR $<0.1$ as the only standard to test the consistency of judgment matrix is considered as a lack of scientific basis by some scholars.

4. A large judgment matrix will increase the difficulty of calculating the maximum eigenvalue of the judgment matrix as well as testing the consistency.

In order to solve the above shortcomings, FAHP - a method that utilizes triangular fuzzy numbers to make fuzzy comparison and judgment between indexes, was proposed by Van Loargoven in 1983. Based on the calculations of triangular fuzzy numbers and the principle of the least square method, the ranking and weights of factors can be obtained. The specific process of the FAHP method are as follows:

(1) Define the triangular fuzzy number and determine the membership function of the fuzzy set.

Assuming the fuzzy number on the domain of discourse $\mathrm{R}$ is $\hat{B}$, if by making $\mathrm{R} \rightarrow[0,1]$, the membership function $\mu_{\hat{B}}(\mathrm{x}): \mathrm{R} \rightarrow[0,1]$ is expressed as

$$
\mu_{\hat{B}}(\mathrm{x})=\left\{\begin{array}{lc}
\frac{x}{m-l}-\frac{l}{m-1}, & l \leq x \leq m \\
\frac{x}{m-u}-\frac{u}{m-u}, & m \leq x \leq u \\
0, & x<l \text { or } x>u
\end{array}\right.
$$

In the above formula, assuming that 1 and $\mathrm{u}$ are the lower and upper bounds of $\hat{B}$ respectively, 
a triangular fuzzy number $\widehat{B}$ can be denoted by a triplet $(\mathrm{l}, \mathrm{m}, \mathrm{u})$ where $1 \leq \mathrm{m} \leq \mathrm{u}$. For the situation of $\mathrm{l}=\mathrm{m}=\mathrm{u}, \hat{B}$ is a definite value in the traditional AHP method.

As shown in Fig. 2, $\mu_{\hat{B}}$ is a trigonometric fuzzy function, and l,u represent the upper and lower bounds of fuzzy numbers respectively.

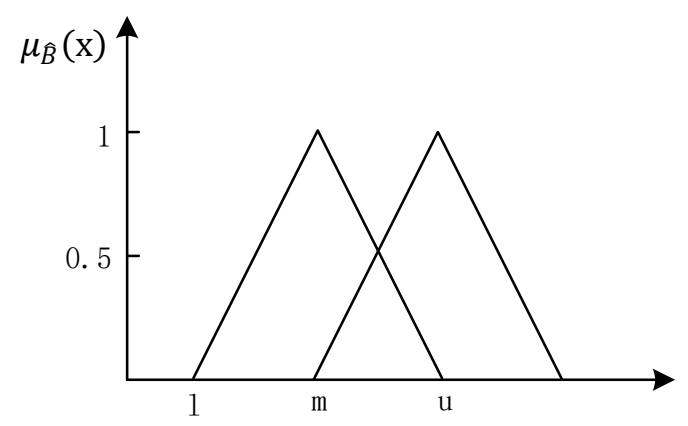

Figure 2 Triangular fuzzy correspondence diagram

(2) Establish the relationship between semantic scale and triangular fuzzy numbers.

Generally, the scaling 1-9 commonly used in AHP, can be employed for reference in the semantic scale of expert evaluation. Considering the fuzziness of subjective judgment, the usual conversion relationship for transforming the determined value into the triangular fuzzy number is shown in Fig. 3.

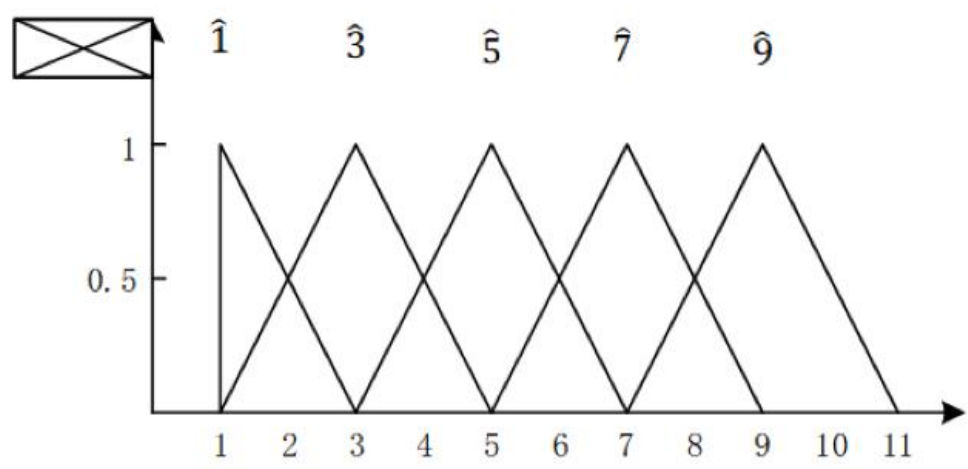

Figure 3 Transforming the determined value into triangular fuzzy number

Triangular fuzzy number $\widehat{\mathrm{B}}_{1}, \widehat{\mathrm{B}}_{3}, \widehat{\mathrm{B}}_{5}, \widehat{\mathrm{B}}_{7}, \widehat{\mathrm{B}}_{9}$ are used to replace the general values $1,3,5$, 7,9 , while $\widehat{\mathrm{B}}_{2}, \widehat{\mathrm{B}}_{4}, \widehat{\mathrm{B}}_{6}, \widehat{\mathrm{B}}_{8}$ are the median values of above adjacent judgments. The trigonometric function transformation relationship of FAHP is shown in Tab. 2.

Table 2 Trigonometric function transformation relationship

score by expert Triangular fuzzy definition numerical representation

number 


\begin{tabular}{cccc}
\hline 3 & $B_{3}$ & weakly important & $(2,3,4)$ \\
5 & $B_{5}$ & Obviously important & $(4,5,6)$ \\
7 & $B_{7}$ & very important & $(6,7,8)$ \\
9 & $B_{9}$ & Extremely important & $(8,9,11)$ \\
$2 、 4 、 6 、 8$ & $B_{2} 、 B_{4} 、 B_{6} 、 B_{8}$ & Median & \\
\hline
\end{tabular}

(3) Determine the synthetic fuzzy value and define its operation method.

Define a set: $\mathrm{X}=\left\{\mathrm{x}_{1}, \mathrm{x}_{2}, \ldots, \mathrm{x}_{\mathrm{n}}\right\}$ as a group of objects and $U=\left\{\mathrm{u}_{1}, \mathrm{u}_{2}, \ldots, \mathrm{u}_{\mathrm{m}}\right\}$ as a set of goals. After analyzing each object aiming at each target, the triangular fuzzy numbers can be obtained in conformity with step (2).

$$
\begin{gathered}
B_{i j}^{1}, B_{i j}^{2}, \cdots, B_{i j}^{M} \\
i=1,2, \cdots, n ; j=1,2, \cdots, n \\
\widehat{B}=\left(b_{i j}\right)_{n \times m}, \quad b_{i j}=\left(l_{i j}, m_{i j}, u_{i j}\right), k=1,2, \cdots, M .
\end{gathered}
$$

When there are $m$ experts making the judgment together, the comprehensive triangular fuzzy number $b_{i j}$ can be expressed as

$$
b_{i j}=\frac{1}{M}\left(b_{i j}{ }^{1} \oplus b_{i j}{ }^{2} \oplus b_{i j}{ }^{3} \oplus \ldots b_{i j}{ }^{M}\right)
$$

The fuzzy value (initial weight) of the ith element in the kth layer is defined as $D_{i}^{k}$ :

$$
\mathrm{D}_{\mathrm{i}}^{\mathrm{k}}=\sum_{\mathrm{j}=1}^{\mathrm{n}} \mathrm{B}_{\mathrm{ij}}^{\mathrm{k}} *\left(\sum_{\mathrm{i}=1}^{\mathrm{n}} \sum_{\mathrm{j}=1}^{\mathrm{n}} \mathrm{B}_{\mathrm{ij}}^{\mathrm{k}}\right)^{-1}
$$

The basic operation method of 3 fuzzy numbers in FAHP method is defined as

$$
\begin{gathered}
\widehat{\mathrm{B}}_{1}=\left(\mathrm{l}_{1}, \mathrm{~m}_{1}, \mathrm{u}_{1}\right) \\
\widehat{\mathrm{B}}_{2}=\left(\mathrm{l}_{2}, \mathrm{~m}_{2}, \mathrm{u}_{2}\right) \\
\widehat{\mathrm{B}}_{1}+\widehat{\mathrm{B}}_{2}=\left(\mathrm{l}_{1}+\mathrm{l}_{2}, \mathrm{~m}_{1}+\mathrm{m}_{2}, \mathrm{u}_{1}+\mathrm{u}_{2}\right) \\
\widehat{\mathrm{B}}_{1} * \widehat{\mathrm{B}}_{2} \approx\left(\mathrm{l}_{1} \mathrm{l}_{2}, \mathrm{~m}_{1} \mathrm{~m}_{2}, \mathrm{u}_{1} \mathrm{u}_{2}\right) \\
\widehat{\mathrm{B}}_{1}^{-1} \approx\left(\frac{1}{\mathrm{u}_{1}}, \frac{1}{\mathrm{~m}_{1}} \cdot \frac{1}{\mathrm{l}_{1}}\right)
\end{gathered}
$$

(4) Single weights of hierarchy to determine the standard weight.

In order to determine the weight vector, the fuzzy sets composed of comprehensive fuzzy value sets are compared. More specifically, the fuzzy numbers $\widehat{B}_{1}=\left(\mathrm{l}_{1}, \mathrm{~m}_{1}, \mathrm{u}_{1}\right)$ and $\widehat{\mathrm{B}}_{2}=$ $\left(\mathrm{l}_{2}, \mathrm{~m}_{2}, \mathrm{u}_{2}\right)$ are compared to specify the possible degree of $\widehat{\mathrm{B}}_{1} \geq \widehat{\mathrm{B}}_{2}$ and $\widehat{\mathrm{B}}_{2} \geq \widehat{\mathrm{B}}_{1}$. The possibility degree of $\widehat{B}_{1} \geq \widehat{B}_{2}$ is defined by the triangular fuzzy function as

$$
\begin{gathered}
\vartheta\left(\widehat{B}_{1} \geq \widehat{B}_{2}\right)=\mu(d)=\sup _{x \geq y}\left[\min \left(u_{\widehat{B}_{1}}(x),\left(u_{\widehat{B}_{2}}(y)\right)\right]\right. \\
\vartheta\left(\widehat{B}_{1} \geq \widehat{B}_{2}\right)= \begin{cases}1 & m_{1} \geq m_{2} \\
\frac{l_{2}-u_{1}}{\left(m_{1}-u_{1}\right)-\left(m_{2}-l_{2}\right)} & m_{1} \leq m_{2}, u_{1} \geq u_{2} \\
0 & \text { otherwise }\end{cases} \\
\vartheta\left(\widehat{B} \geq \widehat{B}_{1}, \quad \widehat{B}_{2}, \quad \cdots, \widehat{B}_{k}\right)=\min \vartheta\left(\widehat{B} \geq \widehat{B}_{i}\right) \quad i=1,2, \cdots, k
\end{gathered}
$$

Where $\mathrm{d}$ corresponds to the ordinate of the highest intersection point $\mathrm{D}$ of two convex membership degrees $\mu_{\widehat{\mathrm{B}}_{1}}$ and $\mu_{\widehat{\mathrm{B}}_{2}}$.

Define the standard weight of one factor as: the possibility degree that a fuzzy number is larger than the other k-1 fuzzy numbers. By comparing all possible fuzzy value $B_{i}(\mathrm{i}=1,2, \ldots, \mathrm{k})$ and weight vector $\vartheta\left(\widehat{B} \geq \widehat{B}_{1}, \widehat{B}_{2}, \ldots, \widehat{B}_{k}\right)$ to obtain the standard weight of this factor.

(5) Total weights of hierarchy to determine the final weight.

$$
W_{i j}=\omega_{i j} * W_{i}
$$


By multiplying $\omega_{i j}$ - the standard weight corresponding to the influencing factor at the lowest level, and $W_{i}$ - the weight of the corresponding factor at the upper level, the final weight of the factor in the hierarchical structure $W_{i j}$ is obtained.

(6) Determine the final ranking in accordance with the final weight.

\subsubsection{Implementation process of FAHP method}

(1) Establishment of hierarchical structure.

According to the above results, the first level factors of the AHP model can be determined asthe KSFs of CLR; the second level factors consist of Principal part of CLR, Key element of CLR projects and System and environment of CLR; and there are 29 third level factors, as shown in the Tab. 3 .

(2) Questionnaire survey in the expert group.

At the stage of using FAHP, this study conducted a questionnaire survey and make statistics on the evaluation results of expert data. Initially, an expert group was established consisting of five members, including two university researchers in the field of CLR, two non-governmental organizations (enterprise) personnel of CLR project, and one staff of a government agency. In order to facilitate the experts to understand and fill in the questionnaire, this study decided to go with a paper questionnaire rather than a digital questionnaire. The questionnaire first introduces the background, purpose, and scoring rules of this survey, and should be filled in by experts to compare the importance of factors at the same level. After overcoming concerns of experts and maintaining their confidentiality, questionnaires were started to filled in respectively.

(3) Construction of fuzzy judgment matrix and data processing.

Based on experience and knowledge, the expert should fill in the questionnaire with the comparison result of the importance of the factors at the same level. After collecting the questionnaires, firstly, the expert semantics is transformed through the triangular fuzzy number conversion relationship table to construct the fuzzy judgment matrix. Secondly, in conformity with the steps in section 4.1.1, defuzzification of the comprehensive triangular fuzzy number corresponding to each factor was performed in the fuzzy judgment matrix, and later, single-level sorting and total sorting were performed to obtain the final weight of the factors. Taking the secondary factor reduction factor B as an example, the fuzzy judgment matrix can be obtained, as shown in Tab. 4.

Table 3 Initial success factors hierarchical structure model

\begin{tabular}{|c|c|c|c|}
\hline $\begin{array}{l}\text { Serial } \\
\text { number }\end{array}$ & Level-2 Index & Level-3 Index & Factors \\
\hline 1 & & $\begin{array}{c}\text { Development plans of the construction land } \\
\text { reduction project }\end{array}$ & A1 \\
\hline 2 & & $\begin{array}{l}\text { Management system of the construction land } \\
\text { reduction project }\end{array}$ & $\mathrm{A} 2$ \\
\hline 3 & & $\begin{array}{l}\text { Coordination organization of the construction land } \\
\text { reduction project }\end{array}$ & A3 \\
\hline 4 & Principal part of & Administrative supervision and management level & A4 \\
\hline 5 & construction land & Qualification and certification process & A5 \\
\hline
\end{tabular}




\begin{tabular}{|c|c|c|c|c|}
\hline 6 & & $\begin{array}{l}\text { reduction } \\
\text { A }\end{array}$ & $\begin{array}{l}\text { Diversity of enterprises participating in the } \\
\text { construction land reduction project }\end{array}$ & A6 \\
\hline 7 & & & Enterprise capacity and competence & A7 \\
\hline 8 & & & Enterprise rules and regulations & A8 \\
\hline 9 & & & Coordination with original landowner & A9 \\
\hline 10 & & & Coordination with surrounding residents & A10 \\
\hline 11 & & & Advance payments for land reclamation & A11 \\
\hline 12 & & & $\begin{array}{l}\text { Status of construction organization for land } \\
\text { remediation and reclamation }\end{array}$ & A12 \\
\hline 13 & Key success & & Standards for land acceptance and testing & B1 \\
\hline 14 & factors of & & Maturity of related technologies & B2 \\
\hline 15 & construction & & Diversity of historical data & B3 \\
\hline 16 & land reduction & Key element of & Scientific land reduction process & B4 \\
\hline 17 & & construction land & Stability of land reduction contract & B5 \\
\hline 18 & & reduction project & Appropriateness of land use planning after reduction & B6 \\
\hline 19 & & B & Consumption of management costs & B7 \\
\hline 20 & & & Consumption of capital & B8 \\
\hline 21 & & & $\begin{array}{l}\text { Diversity of relevant knowledge by land reduction } \\
\qquad \text { staff }\end{array}$ & B9 \\
\hline 22 & & & $\begin{array}{l}\text { Support policy regarding operations of the } \\
\text { construction land reduction project }\end{array}$ & $\mathrm{C} 1$ \\
\hline 23 & & & $\begin{array}{l}\text { Leadership and decision-making mechanisms of the } \\
\text { construction land reduction project }\end{array}$ & $\mathrm{C} 2$ \\
\hline 24 & & & $\begin{array}{c}\text { Coordination mechanism of the construction land } \\
\text { reduction project }\end{array}$ & $\mathrm{C} 3$ \\
\hline 25 & & $\begin{array}{l}\text { System and environment } \\
\text { of construction land }\end{array}$ & $\begin{array}{l}\text { Supervision and evaluation mechanisms of the } \\
\text { construction land reduction project }\end{array}$ & $\mathrm{C} 4$ \\
\hline 26 & & $\begin{array}{l}\text { reduction } \\
\text { C }\end{array}$ & $\begin{array}{l}\text { Financial policies for the construction land } \\
\text { reduction project }\end{array}$ & $\mathrm{C} 5$ \\
\hline 27 & & & $\begin{array}{l}\text { Land policy for the construction land reduction } \\
\text { project }\end{array}$ & C6 \\
\hline 28 & & & $\begin{array}{l}\text { Legal environment of the construction land } \\
\text { reduction project }\end{array}$ & $\mathrm{C} 7$ \\
\hline 29 & & & $\begin{array}{l}\text { Cultural environment of the construction land } \\
\text { reduction project }\end{array}$ & $\mathrm{C} 8$ \\
\hline
\end{tabular}

Table 4 Fuzzy judgment matrix

\begin{tabular}{cccccccccc}
\hline Factors & B1 & B2 & B3 & B4 & B5 & B6 & B7 & B8 & B9 \\
\hline \multirow{2}{*}{ B1 } & $(1.0000,1.000$ & $(3.4000$, & $(1.6500$, & $(1.8000$, & $(2.8000$, & $(0.8500$, & $(1.4286$, & $(3.0400$, & $(3.8000$, \\
& $0,1.0000)$ & 4.0000, & 2.2667, & 2.4000, & 3.6000, & 0.8667, & 2.2333, & 3.6500, & 4.6000, \\
& & $4.8000)$ & $2.9000)$ & $3.0000)$ & $4.4000)$ & $0.9000)$ & $3.0400)$ & $4.2667)$ & $5.6000)$
\end{tabular}




\begin{tabular}{|c|c|c|c|c|c|c|c|c|c|}
\hline B2 & $\begin{array}{l}(0.4915, \\
0.5122, \\
0.5417)\end{array}$ & $\begin{array}{c}(1.0000,1.000 \\
0,1.0000)\end{array}$ & $\begin{array}{l}(2.2500, \\
3.0667 \\
3.9000)\end{array}$ & $\begin{array}{l}(0.8500, \\
0.8667, \\
0.9000)\end{array}$ & $\begin{array}{l}(2.0900, \\
2.7167, \\
3.3667)\end{array}$ & $\begin{array}{l}(0.7500, \\
1.0067, \\
1.3500)\end{array}$ & $\begin{array}{l}(1.4900, \\
2.1167, \\
2.7667)\end{array}$ & $\begin{array}{l}(2.1500, \\
2.6067, \\
3.1500)\end{array}$ & $\begin{array}{l}(2.4667, \\
3.1000, \\
3.8000)\end{array}$ \\
\hline B3 & $\begin{array}{l}(0.7500, \\
1.0067 \\
1.3500)\end{array}$ & $\begin{array}{l}(0.5833, \\
0.8467 \\
1.2000)\end{array}$ & $\begin{array}{c}(1.0000,1.000 \\
0,1.0000)\end{array}$ & $\begin{array}{l}(0.9167 \\
1.1667 \\
1.5000)\end{array}$ & $\begin{array}{l}(2.0000, \\
2.6000, \\
3.2000)\end{array}$ & $\begin{array}{l}(0.9167, \\
1.1667, \\
1.5000)\end{array}$ & $\begin{array}{l}(2.0000, \\
2.6000, \\
3.2000)\end{array}$ & $\begin{array}{l}(2.2500, \\
3.0667, \\
3.9000)\end{array}$ & $\begin{array}{l}(0.7000 \\
1.1333, \\
1.6000)\end{array}$ \\
\hline B4 & $\begin{array}{l}(0.5500, \\
0.6067 \\
0.7500)\end{array}$ & $\begin{array}{l}(1.2000, \\
1.4000 \\
1.6000)\end{array}$ & $\begin{array}{l}(1.0500, \\
1.4667, \\
1.9000)\end{array}$ & $\begin{array}{c}(1.0000,1.000 \\
0,1.0000)\end{array}$ & $\begin{array}{l}(2.0000 \\
2.5000 \\
3.0667)\end{array}$ & $\begin{array}{l}(1.3167, \\
1.7667 \\
2.3000)\end{array}$ & $\begin{array}{l}(2.6333, \\
3.2400 \\
3.8500)\end{array}$ & $\begin{array}{l}(2.8667, \\
3.7000, \\
4.6000)\end{array}$ & $\begin{array}{l}(2.8000, \\
3.6000, \\
4.4000)\end{array}$ \\
\hline B5 & $\begin{array}{l}(0.3650 \\
0.4119 \\
0.5000)\end{array}$ & $\begin{array}{l}(1.1250, \\
1.5619, \\
2.0333)\end{array}$ & $\begin{array}{l}(0.5400 \\
0.5900 \\
0.7167)\end{array}$ & $\begin{array}{l}(0.5452, \\
0.8000 \\
1.1400)\end{array}$ & $\begin{array}{c}(1.0000,1.000 \\
0,1.0000)\end{array}$ & $\begin{array}{l}(2.9000 \\
3.5333 \\
4.2000)\end{array}$ & $\begin{array}{l}(1.8667, \\
2.5000 \\
3.2000)\end{array}$ & $\begin{array}{l}(3.0500, \\
3.6667, \\
4.5000)\end{array}$ & $\begin{array}{l}(2.4500, \\
2.8667, \\
3.5000)\end{array}$ \\
\hline B6 & $\begin{array}{l}(1.2000, \\
1.4000, \\
1.6000)\end{array}$ & $\begin{array}{l}(1.6500, \\
2.2667, \\
2.9000)\end{array}$ & $\begin{array}{l}(1.0500, \\
1.4667, \\
1.9000)\end{array}$ & $\begin{array}{l}(0.8900, \\
1.3167 \\
1.7667)\end{array}$ & $\begin{array}{l}(0.8917 \\
1.3086 \\
1.7333)\end{array}$ & $\begin{array}{c}(1.0000,1.000 \\
0,1.0000)\end{array}$ & $\begin{array}{l}(3.4000 \\
4.4000 \\
5.4000)\end{array}$ & $\begin{array}{l}(4.0000, \\
4.8000 \\
5.8000)\end{array}$ & $\begin{array}{l}(3.0000, \\
3.6000, \\
4.4000)\end{array}$ \\
\hline B7 & $\begin{array}{l}(1.2167, \\
1.5000 \\
1.9000)\end{array}$ & $\begin{array}{l}(1.1500, \\
1.6067 \\
2.1500)\end{array}$ & $\begin{array}{l}(0.5333 \\
0.5733 \\
0.6500)\end{array}$ & $\begin{array}{l}(1.1083, \\
1.3352, \\
1.5833)\end{array}$ & $\begin{array}{l}(0.5400 \\
0.7900 \\
1.0833)\end{array}$ & $\begin{array}{l}(0.2083, \\
0.2752 \\
0.4333)\end{array}$ & $\begin{array}{c}(1.0000,1.000 \\
0,1.0000)\end{array}$ & $\begin{array}{l}(1.9833 \\
2.2667 \\
2.8400)\end{array}$ & $\begin{array}{l}(2.2917 \\
2.9286 \\
3.8333)\end{array}$ \\
\hline B8 & $\begin{array}{l}(0.8917 \\
1.1086 \\
1.3333)\end{array}$ & $\begin{array}{l}(1.4583, \\
2.0686, \\
2.6833)\end{array}$ & $\begin{array}{l}(0.5733 \\
0.8233 \\
1.1167)\end{array}$ & $\begin{array}{l}(0.3500 \\
0.5867 \\
0.8500)\end{array}$ & $\begin{array}{l}(0.6982, \\
0.9222, \\
1.1583)\end{array}$ & $\begin{array}{l}(0.3248, \\
0.3522, \\
0.3917)\end{array}$ & $\begin{array}{l}(1.2182, \\
1.6222, \\
2.2250)\end{array}$ & $\begin{array}{c}(1.0000,1.000 \\
0,1.0000)\end{array}$ & $\begin{array}{l}(2.2667, \\
2.8800, \\
3.5000)\end{array}$ \\
\hline B9 & $\begin{array}{l}(0.3432, \\
0.3841, \\
0.4583)\end{array}$ & $\begin{array}{l}(0.5250 \\
0.7686 \\
1.0833)\end{array}$ & $\begin{array}{l}(1.1333, \\
1.6000 \\
2.2000)\end{array}$ & $\begin{array}{l}(0.3750 \\
0.4352 \\
0.5833)\end{array}$ & $\begin{array}{l}(0.8682, \\
1.0889 \\
1.3250)\end{array}$ & $\begin{array}{l}(0.5182, \\
0.5622, \\
0.6750)\end{array}$ & $\begin{array}{l}(1.5348, \\
1.9889 \\
2.5250)\end{array}$ & $\begin{array}{l}(1.7150, \\
2.1452, \\
2.6000)\end{array}$ & $\begin{array}{c}(1.0000,1.000 \\
0,1.0000)\end{array}$ \\
\hline
\end{tabular}

Similar to the steps above, the final weights of 29 success factors of CLR projects can be calculated. Tab. 5 shows the result of the final weights.

Table 5 Result of the final weights

\begin{tabular}{|c|c|c|c|c|c|}
\hline \multirow{4}{*}{$\begin{array}{l}\text { Key success } \\
\text { factors of }\end{array}$} & Level-2 Index & weight & Level-3 Index & weight & $\begin{array}{l}\text { The total } \\
\text { weight }\end{array}$ \\
\hline & \multirow{9}{*}{$\begin{array}{c}\text { Principal part of } \\
\text { construction land } \\
\text { reduction }\end{array}$} & \multirow{9}{*}{0.5795} & $\begin{array}{l}\text { A1 } \\
\text { A2 }\end{array}$ & 0.171061677 & 0.099132 \\
\hline & & & A3 & 0.131149117 & 0.076002 \\
\hline & & & A4 & 0.095007074 & 0.055057 \\
\hline & & & A5 & 0.077099477 & 0.044680 \\
\hline \multirow{5}{*}{ reduction } & & & A6 & 0.044798431 & 0.025961 \\
\hline & & & A7 & 0.032872266 & 0.019050 \\
\hline & & & A8 & 0.001016952 & 0.000589 \\
\hline & & & A9 & 0.075044813 & 0.043489 \\
\hline & & & A10 & 0.082723132 & 0.047939 \\
\hline
\end{tabular}




\begin{tabular}{|c|c|c|c|c|}
\hline & & $\begin{array}{l}\text { A11 } \\
\text { A12 }\end{array}$ & \begin{tabular}{|l|}
0.095416741 \\
0.032667614 \\
\end{tabular} & $\begin{array}{l}0.055295 \\
0.018931 \\
\end{array}$ \\
\hline $\begin{array}{c}\text { Key element of } \\
\text { construction land } \\
\text { reduction project } \\
\text { B }\end{array}$ & 0.1147 & $\begin{array}{l}\text { B1 } \\
\text { B2 } \\
\text { B3 } \\
\text { B4 } \\
\text { B5 } \\
\text { B6 } \\
\text { B7 } \\
\text { B8 } \\
\text { B9 }\end{array}$ & $\begin{array}{l}0.140247256 \\
0.107174196 \\
0.102713049 \\
0.153595963 \\
0.131557509 \\
0.17492784 \\
0.073978495 \\
0.076537427 \\
0.039268265\end{array}$ & $\begin{array}{l}0.016081 \\
0.012289 \\
0.011777 \\
0.017612 \\
0.015085 \\
0.020058 \\
0.008482 \\
0.008776 \\
0.004503\end{array}$ \\
\hline $\begin{array}{l}\text { System and environment } \\
\text { of construction land } \\
\text { reduction } \\
\text { C }\end{array}$ & 0.3058 & $\begin{array}{l}\mathrm{C} 1 \\
\mathrm{C} 2 \\
\mathrm{C} 3 \\
\mathrm{C} 4 \\
\mathrm{C} 5 \\
\mathrm{C} 6 \\
\mathrm{C} 7\end{array}$ & $\begin{array}{l}0.226615112 \\
0.17298431 \\
0.07037363 \\
0.145067316 \\
0.221723191 \\
0.068478091 \\
0.075646625 \\
0.019111725\end{array}$ & $\begin{array}{l}0.069306 \\
0.052904 \\
0.021522 \\
0.044366 \\
0.067810 \\
0.020943 \\
0.023135 \\
0.005845\end{array}$ \\
\hline
\end{tabular}

\subsection{Analysis of Success Factors Based on Fuzzy-DEMATEL}

The DEMATAL method was used to deal with complex social issues by making full use of the expert's knowledge and experience, which simply and purposefully screen out the key factors. After extending the DEMATEL method to the fuzzy field through the triangular fuzzy semantic scale, it retains the practical and effective advantages of the traditional DEMATEL method. It can not only make the expert's language information be appropriately expressed, but also better reflect the fuzziness of the relationship between factors in the system. Moreover, KSFs can be identified accurately and directly, which improves the credibility of the analysis results.

\subsubsection{The Calculation Steps of Fuzzy-DEMATEL}

The calculation steps of the Fuzzy-DEMATEL method are as follows:

(1) KSFs are constructed by literature references and expert groups, which is set as $\mathrm{B}_{1}, \mathrm{~B}_{2}, \cdots, \mathrm{B}_{\mathrm{n}}$.

(2) Explain the transformation rules of the triangular fuzzy function expert semantic scale.

Through a questionnaire survey, the initial direct impact matrix is determined. According to the degree of influence, the semantic scale used for the expert evaluation is divided into five levels: no influence $(\mathrm{N})$, very low influence $(\mathrm{VL})$, low influence $(\mathrm{L})$, high influence $(\mathrm{H})$, and very high influence (VH). Transform the original scale into a triangular fuzzy number by the semantic transformation. The triangular fuzzy number is generally expressed as $(\mathrm{l}, \mathrm{m}, \mathrm{u})$, in the above 
formula $\mathrm{l} \leq \mathrm{m} \leq \mathrm{u}, \mathrm{l}$, and $\mathrm{u}$ are the lower and upper bounds of the trigonometric function, and $\mathrm{m}$ is the value closest to the actual value. The corresponding relationship between specific semantic evaluation and the triangular fuzzy number is shown in Tab. 6 .

Table 6 The conversion relationship between expert semantic evaluation and triangular fuzzy numbers

\begin{tabular}{ccc}
\hline $\begin{array}{c}\text { Semantic Expression of Level of } \\
\text { Impact Grade }\end{array}$ & $\begin{array}{c}\text { Semantic } \\
\text { Evaluation Value }\end{array}$ & Triangular Fuzzy Number \\
\hline No influence(N) & 0 & $(0,0,0.25)$ \\
Very low influence(VL) & 1 & $(0,0.25,0.5)$ \\
Low influence(L) & 2 & $(0.25,0.5,0.75)$ \\
High influence(H) & 3 & $(0.5,0.75,1)$ \\
Very high influence (VH) & 4 & $(0.75,1,1)$ \\
\hline
\end{tabular}

(3) According to the conversion rules of expert semantic evaluation and trigonometric function in Tab. 6, the expert semantic evaluation in the DEMATEL questionnaire is transformed into the triangular fuzzy numbers, and to obtain a fuzzy matrix $\widetilde{B}_{i j}=\left[\widetilde{a}_{i j}\right]_{n * n}, \quad \widetilde{a}_{i j}=\left(l_{i j}, m_{i j}, u_{i j}\right)$ is the triangular fuzzy number in which factor $i$ affects factor $j$.

(4) Use the CFCS (Converting Fuzzy Data into Crisp Scores) method to defuzzify and weight the left and right scores of the average membership function $\tilde{\mathrm{a}}_{\mathrm{ij}}=\left(\mathrm{l}_{\mathrm{ij}}, \mathrm{m}_{\mathrm{ij}}, \mathrm{u}_{\mathrm{ij}}\right)$. The direct impact matrix of the total score and its composition is obtained. Assuming that that there are $\mathrm{K}$ experts to evaluate the factors of a system by DEMATEL questionnaire, the CFCS method converts triangular fuzzy numbers into accurate values. The steps are as follows.

1) Standardized the triangular fuzzy numbers:

$$
\begin{aligned}
\mathrm{xl}_{i j} & =\frac{\left(l_{i j}-\min _{0 \leq k \leq K} l_{i j}^{k}\right)}{\Delta_{\min }^{\max }} \\
\mathrm{xm}_{i j} & =\frac{\left(m_{i j}-\min _{0 \leq k \leq K} l_{i j}^{k}\right)}{\Delta_{\min }^{\max }}
\end{aligned}
$$

representing,

$$
\Delta_{\min }^{\max }=\max _{0 \leq \mathrm{k} \leq \mathrm{K}} \mathrm{u}_{\mathrm{ij}}^{\mathrm{k}}-\min _{0 \leq \mathrm{k} \leq \mathrm{K}} \mathrm{l}_{\mathrm{ij}}^{\mathrm{k}} \mathrm{xu}_{i j}=\frac{\left(u_{i j}-\min _{0 \leq k \leq K} l_{i j}^{k}\right)}{\Delta_{\min }^{\max }}
$$

2) Standardize the left and right values separately:

$$
\begin{aligned}
\mathrm{xLs}_{i j}^{k} & =\frac{x l_{i j}^{k}}{1+x m_{i j}^{k}-x l_{i j}^{k}} \\
\mathrm{xUs}_{i j}^{k} & =\frac{x u_{i j}^{k}}{1+x m_{i j}^{k}-x l_{i j}^{k}}
\end{aligned}
$$

3) Calculate the clarity value after the expert scores to remove the ambuguity:

$$
\mathrm{x}_{i j}^{k}=\frac{\mathrm{xLs}_{i j}^{k}\left(1-\mathrm{xLs}_{i j}^{k}\right)+\mathrm{xUs}_{i j}^{k} * \mathrm{xUs}_{i j}^{k}}{1-\mathrm{xLs}_{i j}^{k}+\mathrm{xUs} s_{i j}^{k}}
$$




$$
z_{i j}^{k}=\min _{0 \leq k \leq K} l_{i j}^{k}+\mathrm{m}_{i j}^{k} * \Delta_{\min }^{\max }
$$

Among them, $\mathrm{z}_{\mathrm{ij}}^{\mathrm{k}}$ is the clear value obtained after the expert is graded and blurred.

4) Calculate the average clear value scored by $K$ experts, that is, the average impact value:

$$
\mathrm{z}_{i j}=\frac{1}{n}\left(z_{i j}^{1}+z_{i j}^{2}+\cdots+z_{i j}^{k}\right)
$$

5) Standardize the direct matrix to obtain the standard direct impact matrix $X$ :

$$
\mathrm{X}=\left[x_{i j}\right]_{n * n}, 0 \leq \mathrm{x}_{i j} \leq 1
$$

6) Calculate the comprehensive impact matrix $\mathrm{T}$ :

$$
\mathrm{T}=\mathrm{X}(I-X)^{-1}, T=\left[t_{i j}\right]_{n * n^{\prime}}(i, j=1,2,3, \cdots, n)
$$

7) Calculate the influence degree, affected degree, center degree and cause degree of each factor.

The influence degree (D) refers to the comprehensive influence value of the factors corresponding to each row in the matrix $\mathrm{T}$ on all other factors. The affected degree (R) means that the factors corresponding to each column in the matrix $\mathrm{T}$ are affected by all other factors.

$$
\begin{aligned}
\mathrm{D} & =\left[\sum_{i=1}^{n} t_{i j}\right]_{n * 1}=\left[t_{i}\right]_{n * 1} \\
\mathrm{R} & =\left[\sum_{j=1}^{n} t_{i j}\right]_{1 * n}=\left[t_{j}\right]_{1 * n} \\
\mathrm{M}_{\mathrm{i}} & =\mathrm{D}_{\mathrm{i}}+\mathrm{R}_{\mathrm{i}} \\
\mathrm{N}_{\mathrm{i}} & =\mathrm{D}_{\mathrm{i}}-\mathrm{R}_{\mathrm{i}}
\end{aligned}
$$

Where, the centrality $M_{i}$ represents the sum of the influence degree and the affected value of factor $i$, which is used to judge the influence degree of factor $i$ on other factors in the whole system. The greater the centrality, the stronger the driving effect of this factor on other factors. Cause degree $N_{i}$ refers to the influence trend of factor i on the entire system, $N_{i}>0$ indicates that this factor is the cause factor, that is, it will have an active impact on other factors. $N_{i}<0$ indicates that this factor is the result factor, that is, this factor will be affected by other factors.

8) Take the factor centrality degree $M$ and the cause degree $R$ as the Cartesian coordinate system, and mark the position of each factor. Then analyze the importance of each factor and the relationship between them, and put forward practical suggestions.

\subsubsection{Implementation Steps of Fuzzy-DEMATEL}

(1) Determine the expert group: which is consistent with the expert group members of the FAHP questionnaire survey. At this stage, the a questionnaire was used to obtain information through face-to-face interaction. First of all, the questionnaire introduces the background, purpose and scoring rules of the questionnaire survey. After the experts have no objections, according to the corresponding influence degree codes in Tab. 3, they filled in the questionnaires and evaluated the mutual influence degree of factors at all levels. 
(2) Collect questionnaire data and data processing: According to the Tab. 6 of the transformation relation of expert semantic trigonometric function in DEMATEL method, the expert semantics is transformed into the initial fuzzy matrix composed of triangular fuzzy numbers. After defuzzification, the direct impact matrix corresponding to $19 \mathrm{KSFs}$ is obtained.

(3) From the matrix calculation formula, the standard direct impact matrix is calculated, as shown in Tab. 7.

(4) Perform matrix operations by using MATLAB R2017 software, and the comprehensive impact matrix $\mathrm{T}$ is calculated from the standard direct impact matrix $\mathrm{X}$,as shown in Tab. 8 .

$$
\mathrm{T}=\mathrm{X} *(\operatorname{INV}(\operatorname{EYE}(25)-\mathrm{X}))
$$


Table 7 Standard Direct Impact Matrix X

\begin{tabular}{|c|c|c|c|c|c|c|c|c|c|c|c|c|c|c|c|c|c|c|c|c|c|c|c|c|c|c|c|c|c|}
\hline & A1 & A2 & A3 & A4 & A5 & A6 & A7 & A8 & A9 & A10 & A11 & A12 & B1 & B2 & B3 & B4 & B5 & B6 & B7 & B8 & B9 & $\mathrm{C} 1$ & $\mathrm{C} 2$ & C3 & C4 & C5 & C6 & C7 & C8 \\
\hline $\mathrm{A} 1$ & .0089 & 0.0484 & 0.0419 & 0.0404 & 0.0292 & 0.0279 & 0.0197 & 0.0215 & 0.0219 & 0.0209 & 0.0301 & 0.0353 & 0.0404 & 0.0243 & 0.0307 & 0.0234 & 0.0209 & 0.0331 & 0.0316 & 0.0390 & 0.0270 & 0.0419 & 0.0382 & 0.0279 & 0.0279 & 0.0425 & 0.0419 & 0.0367 & 0.0219 \\
\hline A2 & 0.0484 & 0.0089 & 0.0316 & 0.0367 & 0.0316 & 0.0316 & 0.0197 & 0.0200 & 0.0425 & 0.0270 & 0.0264 & 0.0301 & 0.0441 & 0.0390 & 0.0224 & 0.0484 & 0.0307 & 0.0353 & 0.0301 & 0.0354 & 0.0261 & 0.0307 & 0.0422 & 0.0425 & 0.0404 & 0.0382 & 0.0382 & 0.0389 & 0.0151 \\
\hline A3 & 0.0419 & 0.0316 & 0.0089 & 0.0419 & 0.0316 & 0.0264 & 0.0151 & 0.0215 & 0.0343 & 0.0234 & 0.0228 & 0.0301 & 0.0145 & 0.0173 & 0.0160 & 0.0197 & 0.0209 & 0.0234 & 0.0279 & 0.0294 & 0.0173 & 0.0374 & 0.0346 & 0.0422 & 0.0367 & 0.0367 & 0.0279 & 0.0191 & 0.0136 \\
\hline A4 & 0.0404 & 0.0367 & 0.0419 & 0.0089 & 0.0441 & 0.0390 & 0.0353 & 0.0316 & 0.0389 & 0.0307 & 0.0243 & 0.0353 & 0.0441 & 0.0451 & 0.0191 & 0.0353 & 0.0270 & 0.0270 & 0.0374 & 0.0451 & 0.0255 & 0.0367 & 0.0331 & 0.0367 & 0.0404 & 0.0422 & 0.0367 & 0.0441 & 0.0173 \\
\hline A5 & 0.0292 & 0.0316 & 0.0316 & 0.0441 & 0.0089 & 0.0307 & 0.0441 & 0.0331 & 0.0209 & 0.0224 & 0.0224 & 0.0337 & 0.0313 & 0.0419 & 0.0127 & 0.0301 & 0.0255 & 0.0118 & 0.0261 & 0.0261 & 0.0410 & 0.0182 & 0.0219 & 0.0234 & 0.0234 & 0.0197 & 0.0173 & 0.0255 & 0.0133 \\
\hline $\mathrm{A} 6$ & 0.0279 & 0.0316 & 0.0264 & 0.0390 & 0.0307 & 0.0089 & 0.0404 & 0.0467 & 0.0255 & 0.0246 & 0.0292 & 0.0353 & 0.0316 & 0.0484 & 0.0255 & 0.0270 & 0.0404 & 0.0219 & 0.0338 & 0.0467 & 0.0467 & 0.0270 & 0.0191 & 0.0264 & 0.0389 & 0.0270 & 0.0322 & 0.0178 & 0.0136 \\
\hline A7 & 0.0197 & 0.0197 & 0.0151 & 0.0353 & 0.0441 & 0.0404 & 0.0089 & 0.0473 & 0.0276 & 0.0230 & 0.0142 & 0.0224 & 0.0160 & 0.0457 & 0.0151 & 0.0219 & 0.0406 & 0.0255 & 0.0404 & 0.0484 & 0.0564 & 0.0298 & 0.0173 & 0.0173 & 0.0164 & 0.0209 & 0.0164 & 0.0164 & 0.0107 \\
\hline $\mathrm{A} 8$ & 0.0215 & 0.0200 & 0.0215 & 0.0316 & 0.0331 & 0.0467 & 0.0473 & 0.0089 & 0.0136 & 0.0127 & 0.0118 & 0.0200 & 0.0136 & 0.0279 & 0.0164 & 0.0301 & 0.0292 & 0.0127 & 0.0404 & 0.0395 & 0.0395 & 0.0164 & 0.0164 & 0.0136 & 0.0127 & 0.0164 & 0.0164 & 0.0173 & 0.0164 \\
\hline A9 & 0.0219 & 0.0425 & 0.0343 & 0.0389 & 0.0209 & 0.0255 & 0.0276 & 0.0136 & 0.0089 & 0.0182 & 0.0219 & 0.0255 & 0.0173 & 0.0118 & 0.0373 & 0.0219 & 0.0209 & 0.0197 & 0.0285 & 0.0285 & 0.0142 & 0.0209 & 0.0380 & 0.0365 & 0.0307 & 0.0322 & 0.0209 & 0.0200 & 0.0209 \\
\hline A10 & 0.0209 & 0.0270 & 0.0234 & 0.0307 & 0.0224 & 0.0246 & 0.0230 & 0.0127 & 0.0182 & 0.0089 & 0.0219 & 0.0234 & 0.0066 & 0.0089 & 0.0230 & 0.0224 & 0.0224 & 0.0219 & 0.0224 & 0.0224 & 0.0133 & 0.0270 & 0.0261 & 0.0261 & 0.0298 & 0.0313 & 0.0261 & 0.0200 & 0.0246 \\
\hline A11 & 0.0301 & 0.0264 & 0.0228 & 0.0243 & 0.0224 & 0.0292 & 0.0142 & 0.0118 & 0.0219 & 0.0219 & 0.0089 & 0.0283 & 0.0136 & 0.0145 & 0.0234 & 0.0191 & 0.0255 & 0.0303 & 0.0301 & 0.0374 & 0.0173 & 0.0353 & 0.0301 & 0.0301 & 0.0301 & 0.0353 & 0.0338 & 0.0219 & 0.0219 \\
\hline A12 & 0.0353 & 0.0301 & 0.0301 & 0.0353 & 0.0337 & 0.0353 & 0.0224 & 0.0200 & 0.0255 & 0.0234 & 0.0283 & 0.0089 & 0.0224 & 0.0410 & 0.0222 & 0.0374 & 0.0409 & 0.0255 & 0.0316 & 0.0389 & 0.0441 & 0.0343 & 0.0219 & 0.0264 & 0.0264 & 0.0322 & 0.0292 & 0.0255 & 0.0219 \\
\hline B1 & 0.0404 & 0.0441 & 0.0145 & 0.0441 & 0.0313 & 0.0316 & 0.0160 & 0.0136 & 0.0173 & 0.0066 & 0.0136 & 0.0224 & 0.0089 & 0.0564 & 0.0380 & 0.0451 & 0.0380 & 0.0219 & 0.0219 & 0.0270 & 0.0301 & 0.0246 & 0.0261 & 0.0261 & 0.0261 & 0.0283 & 0.0298 & 0.0374 & 0.0187 \\
\hline B2 & 0.0243 & 0.0390 & 0.0173 & 0.0451 & 0.0419 & 0.0484 & 0.0457 & 0.0279 & 0.0118 & 0.0089 & 0.0145 & 0.0410 & 0.0564 & 0.0089 & 0.0209 & 0.0390 & 0.0390 & 0.0234 & 0.0404 & 0.0404 & 0.0441 & 0.0285 & 0.0151 & 0.0173 & 0.0173 & 0.0292 & 0.0197 & 0.0307 & 0.0182 \\
\hline B3 & 0.0307 & 0.0224 & 0.0160 & 0.0191 & 0.0127 & 0.0255 & 0.0151 & 0.0164 & 0.0373 & 0.0230 & 0.0234 & 0.0222 & 0.0380 & 0.0209 & 0.0089 & 0.0365 & 0.0301 & 0.0307 & 0.0255 & 0.0292 & 0.0219 & 0.0246 & 0.0200 & 0.0200 & 0.0215 & 0.0224 & 0.0209 & 0.0209 & 0.0209 \\
\hline B4 & 0.0234 & 0.0484 & 0.0197 & 0.0353 & 0.0301 & 0.0270 & 0.0219 & 0.0301 & 0.0219 & 0.0224 & 0.0191 & 0.0374 & 0.0451 & 0.0390 & 0.0365 & 0.0089 & 0.0358 & 0.0441 & 0.0243 & 0.0319 & 0.0279 & 0.0389 & 0.0322 & 0.0307 & 0.0279 & 0.0234 & 0.0234 & 0.0270 & 0.0209 \\
\hline B5 & 0.0209 & 0.0307 & 0.0209 & 0.0270 & 0.0255 & 0.0404 & 0.0406 & 0.0292 & 0.0209 & 0.0224 & 0.0255 & 0.0409 & 0.0380 & 0.0390 & 0.0301 & 0.0358 & 0.0089 & 0.0307 & 0.0307 & 0.0307 & 0.0209 & 0.0246 & 0.0209 & 0.0209 & 0.0209 & 0.0224 & 0.0246 & 0.0246 & 0.0246 \\
\hline B6 & 0.0331 & 0.0353 & 0.0234 & 0.0270 & 0.0118 & 0.0219 & 0.0255 & 0.0127 & 0.0197 & 0.0219 & 0.0303 & 0.0255 & 0.0219 & 0.0234 & 0.0307 & 0.0441 & 0.0307 & 0.0089 & 0.0422 & 0.0422 & 0.0285 & 0.0160 & 0.0197 & 0.0243 & 0.0206 & 0.0316 & 0.0353 & 0.0219 & 0.0153 \\
\hline B7 & 0.0316 & 0.0301 & 0.0279 & 0.0374 & 0.0261 & 0.0338 & 0.0404 & 0.0404 & 0.0285 & 0.0224 & 0.0301 & 0.0316 & 0.0219 & 0.0404 & 0.0255 & 0.0243 & 0.0307 & 0.0422 & 0.0089 & 0.0517 & 0.0239 & 0.0224 & 0.0261 & 0.0261 & 0.0224 & 0.0343 & 0.0234 & 0.0173 & 0.0136 \\
\hline B8 & 0.0390 & 0.0354 & 0.0294 & 0.0451 & 0.0261 & 0.0467 & 0.0484 & 0.0395 & 0.0285 & 0.0224 & 0.0374 & 0.0389 & 0.0270 & 0.0404 & 0.0292 & 0.0319 & 0.0307 & 0.0422 & 0.0517 & 0.0089 & 0.0270 & 0.0270 & 0.0151 & 0.0151 & 0.0188 & 0.0285 & 0.0285 & 0.0164 & 0.0107 \\
\hline B9 & 0.0270 & 0.0261 & 0.0173 & 0.0255 & 0.0410 & 0.0467 & 0.0564 & 0.0395 & 0.0142 & 0.0133 & 0.0173 & 0.0441 & 0.0301 & 0.0441 & 0.0219 & 0.0279 & 0.0209 & 0.0285 & 0.0239 & 0.0270 & 0.0089 & 0.0142 & 0.0179 & 0.0197 & 0.0188 & 0.0179 & 0.0142 & 0.0179 & 0.0215 \\
\hline $\mathrm{C} 1$ & 0.0419 & 0.0307 & 0.0374 & 0.0367 & 0.0182 & 0.0270 & 0.0298 & 0.0164 & 0.0209 & 0.0270 & 0.0353 & 0.0343 & 0.0246 & 0.0285 & 0.0246 & 0.0389 & 0.0246 & 0.0160 & 0.0224 & 0.0270 & 0.0142 & 0.0089 & 0.0425 & 0.0331 & 0.0367 & 0.0425 & 0.0354 & 0338 & .0173 \\
\hline $\mathrm{C} 2$ & 0.0382 & 0.0422 & 0.0346 & 0.0331 & 0.0219 & 0.0191 & 0.0173 & 0.0164 & 0.0380 & 0.0261 & 0.0301 & 0.0219 & 0.0261 & 0.0151 & 0.0200 & 0.0322 & 0.0209 & 0.0197 & 0.0261 & 0.0151 & 0.0179 & 0.0425 & 0.0089 & 0.0406 & 0.0367 & 0.0406 & 0.0370 & 0.0228 & .0182 \\
\hline C3 & 0.0279 & 0.0425 & 0.0422 & 0.0367 & 0.0234 & 0.0264 & 0.0173 & 0.0136 & 0.036 & 0.0261 & 0.0301 & 0.0264 & 0.0261 & 0.0173 & 0.0200 & 0.0307 & 0.0209 & 0.0243 & 0.0261 & 0.0151 & 0.0197 & 0.0331 & 406 & 1089 & 0219 & 0.0255 & 0.0283 & 0.0173 & 0.0133 \\
\hline C4 & 0.0279 & 0.0404 & 0.0367 & 0.0404 & 0.0234 & 0.0389 & 0.0164 & 0.0127 & 0.0307 & 0.0298 & 0.03 & 0.0264 & 0.0261 & 0.0173 & 0.0215 & 0.0279 & 0.0209 & 0.0206 & 0.0224 & 0.0188 & 0.0188 & 67 & 67 & 219 & 0.0089 & 0.0292 & 0.0246 & 0.0173 & 0.0107 \\
\hline C5 & 0.0425 & 0.0382 & 0.0367 & 0.0422 & 0.0197 & 0.0270 & 0.0209 & 0.0164 & 0.032 & 0.03 & 0.03 & 0.0322 & 0.0283 & 0.0292 & 0.0224 & 0.0234 & 0.0224 & 0.0316 & 0.0343 & 0.0285 & 0.0179 & 0.0425 & 0.0406 & 0.0255 & 0.0292 & 0.0089 & 0.0425 & 0.0279 & 0.0228 \\
\hline C6 & 0.0419 & 0.0382 & 0.0279 & 0.0367 & 0.017 & 0.0322 & 0.016 & 0.016 & 0.02 & 0.02 & 0.03 & 0.02 & 0.02 & 0.0 & 0.0 & 0.0234 & 0.0246 & 0.0353 & 0.0234 & 0.0285 & 42 & 354 & 370 & 283 & 246 & 425 & 089 & 0228 & 91 \\
\hline $\mathrm{C} 7$ & 0.0367 & 0.0389 & 0.0191 & 0.044 & 0.0255 & 0.0178 & 0.016 & 0.017 & 0.02 & 0.02 & 0.02 & 0.02 & 0.0 & 0.0 & 0.0 & 0.0277 & 0.0246 & 0.0219 & 0.0173 & 0.0164 & 0.0179 & 0.0338 & 228 & 173 & 173 & 279 & 0228 & 0899 & 0.0338 \\
\hline C8 & .0219 & 0.0151 & .0136 & .0173 & 10133 & 10136 & .0107 & D.0164 & 0.0209 & 0.0246 & 0.0219 & 0.0219 & 0.0187 & 0.0182 & 0.0180 & 0.0209 & 0.0246 & .0182 & 0.0136 & 0.0107 & 0.0215 & 0.0173 & 0.0182 & 0.0133 & 0.0107 & 0.0228 & 0.0191 & 0.0338 & 0.0089 \\
\hline
\end{tabular}


Table 8 Comprehensive Impact Matrix T

\begin{tabular}{|c|c|c|c|c|c|c|c|c|c|c|c|c|c|c|c|c|c|c|c|c|c|c|c|c|c|c|c|c|c|}
\hline & $\mathrm{A} 1$ & A2 & A3 & $\mathrm{A} 4$ & A5 & A6 & A7 & A8 & A9 & $\mathrm{A} 10$ & A11 & A12 & B1 & B2 & B3 & B4 & B5 & B6 & B7 & B8 & B9 & C1 & C2 & C3 & C4 & C5 & C6 & C7 & C8 \\
\hline $\mathrm{A} 1$ & 0.1479 & 1934 & 0.1595 & 0.1927 & 1460 & 0.1634 & 0.1375 & 1235 & 1331 & 1177 & 0.1394 & 1650 & 0.1641 & .1567 & 0.1332 & 1545 & 419 & 0.1480 & 0.1593 & 0.1745 & 0.1400 & 0.1686 & 0.1577 & 0.1421 & 1419 & 1732 & 1616 & 1.1447 & 1003 \\
\hline A2 & 0.1934 & 1654 & 1570 & 1990 & 1557 & 1754 & 1450 & 1283 & 1591 & 1291 & 1422 & 1684 & 1759 & 1786 & 1324 & 1863 & 1587 & 0.1572 & 0.1657 & 0.1793 & 0.1463 & 0.1658 & 0.1689 & 0.1629 & 1606 & 1768 & 1650 & 1532 & 0988 \\
\hline A3 & 0.1595 & 1570 & 1120 & 1725 & 1316 & 1427 & 0.1167 & 1089 & 1296 & 1067 & 0.1171 & 1416 & 0.1211 & 0.1301 & 0.1044 & 0.1317 & 0.1241 & 0.1218 & 0.1377 & 0.1459 & 0.1143 & 0.1465 & 0.1379 & 0.1398 & 0.1345 & .1492 & .1312 & 0.1120 & 0.0809 \\
\hline A4 & 0.1927 & 0.1990 & 0.1725 & 0.1801 & 0.1743 & 0.1900 & 0.1671 & 1457 & 1610 & 0.1374 & 0.1454 & 0.1799 & 0.1816 & 0.1920 & 0.1338 & 0.1801 & 0.1618 & 0.1546 & 0.1797 & 0.1960 & 0.1526 & 0.1776 & 0.1656 & 0.1626 & 0.1660 & 0.1868 & 0.1691 & 0.1633 & 0.1045 \\
\hline A5 & 0.1460 & 1557 & 0.1316 & 0.1743 & 0.1116 & 0.1483 & 0.1465 & 0.1223 & 1152 & 0.1043 & 0.1146 & 0.1453 & 0.1378 & 0.1563 & 0.1007 & 0.1417 & 0.1298 & 0.1105 & 0.1363 & 0.1439 & 0.1397 & 0.1268 & 0.1232 & 0.1202 & 0.1202 & 0.1310 & 0.1190 & 0.1179 & 0.0805 \\
\hline A6 & 0.1634 & 0.1754 & 0.1427 & 0.1900 & 0.1483 & 0.1464 & 0.1599 & 0.1494 & 1344 & 0.1196 & 0.1365 & 0.1649 & 0.1548 & 0.1803 & 0.1274 & 0.1568 & 0.1606 & 0.1363 & 0.1618 & 0.1825 & 0.1605 & 0.1521 & 0.1366 & 0.1381 & 0.1502 & 0.1557 & 0.1495 & 0.1246 & 0.0913 \\
\hline A7 & 0.1375 & 0.1450 & 0.1167 & 0.1671 & 0.1465 & 0.1599 & 0.1164 & 0.1383 & 0.1217 & 0.1055 & 0.1081 & 0.1366 & 0.1241 & 0.1618 & 0.1042 & 0.1352 & 0.1454 & 0.1248 & 0.1522 & 0.1672 & 0.1559 & 0.1374 & 0.1187 & 0.1144 & 0.1138 & 0.1327 & 0.1186 & 0.1092 & 0.0784 \\
\hline A8 & 0.1235 & 0.1283 & 0.1089 & 0.1457 & 0.1223 & 0.1494 & 0.1383 & 0.0893 & 0.0962 & 0.0848 & 0.0931 & 0.1186 & 0.1073 & 0.1295 & 0.0932 & 0.1273 & 0.1207 & 0.0996 & 0.1369 & 0.1428 & 0.1267 & 0.1106 & 0.1042 & 0.0980 & 0.0973 & 0.1133 & 0.1049 & 0.0975 & 0.0746 \\
\hline A9 & 0.1331 & 0.1592 & 0.1296 & 0.1610 & 0.1152 & 0.1344 & 0.1218 & 0.0962 & 0.0996 & 0.0967 & 0.1101 & 0.1299 & 0.1173 & 0.1182 & 0.1194 & 0.1271 & 0.1182 & 0.1127 & 0.1315 & 0.1378 & 0.1056 & 0.1238 & 0.1343 & 0.1283 & 0.1225 & 0.1374 & 0.1178 & 0.1070 & 0.0838 \\
\hline $\mathrm{A} 10$ & 0.1177 & 0.1291 & 0.1067 & 0.1374 & 0.1043 & 0.1196 & 0.1055 & 0.0848 & 0.0967 & 0.0777 & 0.0991 & 0.1147 & 0.0940 & 0.1016 & 0.0950 & 0.1139 & 0.1072 & 0.1028 & 0.1123 & 0.1180 & 0.0930 & 0.1165 & 0.1104 & 0.1061 & 0.1097 & 0.1231 & 0.1104 & 0.0959 & 0.0796 \\
\hline A11 & 0.1394 & 0.1422 & 0.1171 & 0.1454 & 0.1146 & 0.1365 & 0.1081 & 0.0931 & 0.1101 & 0.0991 & 0.0967 & 0.1316 & 0.1121 & 0.1191 & 0.1051 & 0.1228 & 0.1211 & 0.1217 & 0.1316 & 0.1448 & 0.1069 & 0.1359 & 0.1252 & 0.1203 & 0.1203 & 0.1391 & 0.1290 & 0.1074 & 0.0840 \\
\hline $\mathrm{A} 12$ & 0.1650 & 0.1684 & 0.1416 & 0.1799 & 0.1453 & 0.1649 & 0.1366 & 0.1186 & 0.1299 & 0.1147 & 0.1316 & 0.1339 & 0.1413 & 0.1670 & 0.1202 & 0.1610 & 0.1555 & 0.1352 & 0.1534 & 0.1684 & 0.1520 & 0.1542 & 0.1349 & 0.1340 & 0.1340 & 0.1557 & 0.1423 & 0.1280 & 0.0964 \\
\hline B1 & 0.1641 & 0.1759 & 0.1211 & 0.1816 & 0.1378 & 0.1548 & 0.1241 & 0.1073 & 0.1173 & 0.0940 & 0.1121 & 0.1413 & 0.1245 & 0.1762 & 0.1308 & 0.1635 & 0.1475 & 0.1265 & 0.1379 & 0.1505 & 0.1335 & 0.1395 & 0.1337 & 0.1285 & 0.1285 & 0.1460 & 0.1375 & 0.1355 & 0.0900 \\
\hline B2 & 0.1567 & 0.1786 & 0.1301 & 0.1920 & 0.1563 & 0.1803 & 0.1618 & 0.1295 & 0.1182 & 0.1016 & 0.1191 & 0.1670 & 0.1762 & 0.1413 & 0.1205 & 0.1655 & 0.1569 & 0.1348 & 0.1642 & 0.1731 & 0.1560 & 0.1498 & 0.1291 & 0.1262 & 0.1265 & 0.1539 & 0.1345 & 0.1350 & 0.0937 \\
\hline B3 & 0.1335 & 0.1327 & 0.1046 & 0.1341 & 0.1009 & 0.1276 & 0.1044 & 0.0934 & 0.1197 & 0.0952 & 0.1053 & 0.1204 & 0.1311 & 0.1208 & 0.0876 & 0.1347 & 0.1212 & 0.1175 & 0.1218 & 0.1317 & 0.1073 & 0.1198 & 0.1100 & 0.1056 & 0.1069 & 0.1207 & 0.1110 & 0.1024 & 0.0803 \\
\hline B4 & 0.1545 & 0.1863 & 0.1317 & 0.1801 & 0.1417 & 0.1568 & 0.1352 & 0.1273 & 0.1271 & 0.1139 & 0.1228 & 0.1610 & 0.1635 & 0.1655 & 0.1344 & 0.1351 & 0.1514 & 0.1528 & 0.1466 & 0.1616 & 0.1368 & 0.1586 & 0.1451 & 0.1385 & 0.1357 & 1476 & 1372 & .1303 & 0.0956 \\
\hline B5 & 0.1419 & 0.1587 & 0.1241 & 0.1618 & 0.1298 & 0.1606 & 0.1454 & 0.1207 & 0.1182 & 0.1071 & 0.1211 & 0.1555 & 0.1475 & 0.1569 & 0.1210 & 0.1514 & 0.1174 & 0.1322 & 0.1442 & 0.1521 & 0.1235 & 0.1361 & 0.1253 & 0.1207 & 0.1208 & 0.1373 & .1296 & 11199 & 0.0937 \\
\hline B6 & 0.1477 & 0.1569 & 0.1216 & 0.1544 & 0.1103 & 0.1360 & 0.1246 & 0.0994 & 0.1124 & 0.1026 & 0.1214 & 0.1349 & 0.1263 & 0.1345 & 0.1170 & 0.1526 & 0.1319 & 0.1069 & 0.1491 & 0.1563 & 0.1233 & 0.1226 & 0.1196 & 1192 & 1154 & 1406 & 1349 & 1119 & 0.0811 \\
\hline B7 & 0.1593 & 0.1657 & 0.1377 & 0.1797 & 0.1363 & 0.1618 & 0.1522 & 0.1369 & 0.1314 & 0.1123 & 0.1316 & 0.1534 & 0.1379 & 0.1642 & 0.1216 & 0.1466 & 0.1442 & 0.1493 & 0.1306 & 0.1796 & 0.1318 & 0.1406 & 0.1366 & 0.1316 & 0.1281 & .1556 & 1349 & 1179 & 67 \\
\hline B8 & 0.1745 & 0.1793 & 0.1459 & 0.1960 & 0.1439 & 0.1825 & 0.1672 & 0.1428 & 0.1378 & 0.1180 & 0.1448 & 0.1684 & 0.1505 & 0.1731 & 0.1314 & 0.1616 & 0.15 & 0.1565 & 0.1796 & 0.1477 & 0.1422 & 0.1525 & 0.1332 & 0.1281 & 0.1317 & 0.1581 & 0.1470 & 0.1237 & 0.0886 \\
\hline B9 & 0.1400 & 0.1463 & 0.1143 & 0.1526 & 1397 & 0.1605 & 0.1559 & 0.1267 & 10 & 0.0930 & 0.1069 & 0.1520 & 0.1335 & 0.1560 & 0.1070 & 0.136 & 0.1235 & 0.1235 & 0.1318 & 0.1422 & 0.1075 & 0.1191 & 0.1153 & .1130 & 0.1123 & 0.1253 & 0.1128 & 0.1074 & 0.0862 \\
\hline $\mathrm{C} 1$ & 0.1686 & 0.1658 & 0.1465 & 0.1776 & 0.1268 & 0.1521 & 0 & 106 & 1238 & & 0.1359 & 15 & & & & 158 & & 12 & & 1.1525 & & 0.1 & 0.1531 & 0.1384 & 0.1418 & 0.1633 & 0.1462 & 0.1334 & 0.0901 \\
\hline $\mathrm{C} 2$ & & & & & & & & & & & & 49 & 0.1337 & 0.1291 & 0.1097 & 1451 & 0.1253 & 0.1199 & 0.1366 & 0.1332 & 0.1153 & 0.1531 & 0.1150 & 0.1400 & 0.1360 & 0.1545 & .1413 & 11170 & 0.0865 \\
\hline C. & & 1629 & & & 1202 & 1381 & 0.1144 & 0.0980 & & 0.10 & & 0 & 0.1285 & 0.1262 & 0.1054 & & 0.1207 & 0.1194 & 0.1316 & 0.1281 & 0.1130 & 0.1384 & 0.1400 & 0.1047 & 0.1171 & 0.1345 & 0.1277 & 0.1071 & 0.0784 \\
\hline C4 & 0.1419 & 0.1606 & 0.1345 & 0.1660 & 0.1202 & 0.1502 & 0.1138 & 0.0973 & 0.1225 & 0.1097 & 0.1203 & 0.1340 & 0.1285 & 0.1265 & 0.1067 & 0.1357 & 0.1208 & 0.1156 & 0.1281 & 0.1317 & 0.1123 & 0.1418 & 0.1360 & 0.1171 & 0.1044 & 0.1378 & .1242 & 0.1070 & 0.0757 \\
\hline C5 & 0.1732 & 0.1768 & 0.1492 & 0.1868 & 0.1310 & 0.1557 & 0.1327 & 0.1132 & 0.1374 & 0.1231 & 0.13 & 0.1557 & 0.1460 & 0.1539 & 0.12 & 14 & . 13 & 0.1409 & 0.1556 & 0.15 & 0.1253 & 0.1633 & 0.1545 & 0.1345 & 0.1378 & 0.1348 & 0.1565 & 0.1310 & 0.0974 \\
\hline C6 & 0.1616 & 0.1650 & 0.1312 & 0.1691 & 0.1190 & 0.14 & 0.1186 & 0.1049 & 0.1177 & 0. & 0.1290 & 0.1423 & 75 & 0.13 & 0.11 & 0.1372 & 0.1296 & 0.1352 & 0 & 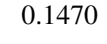 & 8 & 62 & 0.1413 & 0.1277 & 0.1242 & 0.1565 & .1145 & 1173 & 0875 \\
\hline C7 & 0.1447 & 0.1532 & 0.1120 & 0.1633 & 0.1179 & 0.1246 & 0.1092 & 0.0975 & 0.1070 & 0.0959 & 0.1074 & 30 & 1355 & 0.1350 & 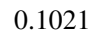 & 303 & & & & 0.1231 & 0.1075 & 0.1334 & 71 & 71 & 1070 & 1310 & 1173 & 0.0954 & 0.0955 \\
\hline C8 & 0.1003 & 0.0988 & 0.0809 & 0.1046 & 0.0805 & 0.0913 & 0.0785 & 0.0747 & 0.0838 & 0.0796 & 0.0841 & 0.0965 & 0.0899 & 0.0938 & 0.0773 & 0.0957 & 0.0937 & 0.0841 & 0.0868 & 0.0887 & 0.0863 & 0.0901 & 0.0866 & 0.0785 & 0.0757 & 0.0975 & 0.0876 & 0.0955 & 0.0547 \\
\hline
\end{tabular}


(5) Using Excel and MATLAB software, calculate the influence degree D and the affected degree $\mathrm{R}$ of each factor from the comprehensive impact matrix, and calculate the centrality and cause degree by the formula in 4.2.1. The results are shown in Tab. 9.

Table 9 Calculation results of "four degrees" of construction land reduction project

\begin{tabular}{|c|c|c|c|c|c|}
\hline Success factors & $\begin{array}{l}\text { Factor } \\
\text { code }\end{array}$ & $\begin{array}{l}\text { Influence } \\
\text { degree D }\end{array}$ & $\begin{array}{l}\text { Affected } \\
\text { degree R }\end{array}$ & $\begin{array}{l}\text { Cause degree } \\
\qquad \mathrm{D}+\mathrm{R}\end{array}$ & $\begin{array}{l}\text { Centrality } \\
\text { degree D-R }\end{array}$ \\
\hline $\begin{array}{c}\text { Development plans of the construction land } \\
\text { reduction project }\end{array}$ & A1 & 4.38152871 & 4.381567676 & 8.763096386 & -0.000039 \\
\hline $\begin{array}{c}\text { Management system of the construction land } \\
\text { reduction project }\end{array}$ & $\mathrm{A} 2$ & 4.650493101 & 4.650636641 & 9.301129742 & -0.000144 \\
\hline $\begin{array}{l}\text { Coordination organization of the construction } \\
\text { land reduction project }\end{array}$ & $\mathrm{A} 3$ & 3.759064461 & 3.75915308 & 7.518217542 & -0.000089 \\
\hline $\begin{array}{l}\text { Administrative supervision and management } \\
\text { level }\end{array}$ & A4 & 4.872810057 & 4.872907354 & 9.745717412 & -0.000097 \\
\hline Qualification and certification process & A5 & 3.751469488 & 3.751479743 & 7.502949231 & -0.000010 \\
\hline $\begin{array}{l}\text { Diversity of enterprises participating in the } \\
\text { construction land reduction project }\end{array}$ & A6 & 4.349867769 & 4.349856907 & 8.699724677 & 0.000011 \\
\hline Enterprise capacity and competence & A7 & 3.793441595 & 3.793565587 & 7.587007181 & -0.000124 \\
\hline Enterprise rules and regulations & A8 & 3.282763008 & 3.282744782 & 6.56550779 & 0.000018 \\
\hline Coordination with original landowner & A9 & 3.529423464 & 3.529260413 & 7.058683876 & 0.000163 \\
\hline Coordination with surrounding residents & A10 & 3.082749812 & 3.082740842 & 6.165490655 & 0.000009 \\
\hline Advance payments for land reclamation & A11 & 3.480395538 & 3.480471889 & 6.960867427 & -0.000076 \\
\hline $\begin{array}{l}\text { Status of construction organization for land } \\
\text { remediation and reclamation }\end{array}$ & A12 & 4.163665142 & 4.163711147 & 8.327376289 & -0.000046 \\
\hline Standards for land acceptance and testing & B1 & 3.961632019 & 3.961487531 & 7.92311955 & 0.000144 \\
\hline Maturity of related technologies & $\mathrm{B} 2$ & 4.22832039 & 4.228361574 & 8.456681964 & -0.000041 \\
\hline Diversity of historical data & B3 & 3.302160472 & 3.292129805 & 6.594290278 & 0.010031 \\
\hline Scientific land reduction process & B4 & 4.174952296 & 4.175034425 & 8.349986721 & -0.000082 \\
\hline Stability of land reduction contract & B5 & 3.874524568 & 3.874535062 & 7.74905963 & -0.000010 \\
\hline
\end{tabular}




\begin{tabular}{|c|c|c|c|c|c|}
\hline $\begin{array}{l}\text { Appropriateness of land use planning after } \\
\text { reduction }\end{array}$ & B6 & 3.665280133 & 3.675333433 & 7.340613567 & -0.010053 \\
\hline Consumption of management costs & B7 & 4.096091285 & 4.096278606 & 8.192369891 & -0.000187 \\
\hline Consumption of capital & $\mathrm{B} 8$ & 4.358634255 & 4.358792345 & 8.7174266 & -0.000158 \\
\hline $\begin{array}{c}\text { Diversity of relevant knowledge by land } \\
\text { reduction staff }\end{array}$ & B9 & 3.646698085 & 3.646771139 & 7.293469224 & -0.000073 \\
\hline $\begin{array}{l}\text { Support policy regarding operations of the } \\
\text { construction land reduction project }\end{array}$ & $\mathrm{C} 1$ & 4.048819457 & 4.048753435 & 8.097572892 & 0.000066 \\
\hline $\begin{array}{l}\text { Leadership and decision-making mechanisms } \\
\text { of the construction land reduction project }\end{array}$ & $\mathrm{C} 2$ & 3.809019978 & 3.809027137 & 7.618047115 & -0.000007 \\
\hline $\begin{array}{l}\text { Coordination mechanism of the construction } \\
\text { land reduction project }\end{array}$ & $\mathrm{C} 3$ & 3.626047071 & 3.626102984 & 7.252150055 & -0.000056 \\
\hline $\begin{array}{l}\text { Supervision and evaluation mechanisms of the } \\
\text { construction land reduction project }\end{array}$ & $\mathrm{C} 4$ & 3.620532021 & 3.620539158 & 7.241071179 & -0.000007 \\
\hline $\begin{array}{l}\text { Financial policies for the construction land } \\
\text { reduction project }\end{array}$ & $\mathrm{C} 5$ & 4.168876469 & 4.168977013 & 8.337853482 & -0.000101 \\
\hline $\begin{array}{l}\text { Land policy for the construction land reduction } \\
\text { project }\end{array}$ & $\mathrm{C} 6$ & 3.81289607 & 3.813048024 & 7.625944093 & -0.000152 \\
\hline $\begin{array}{l}\text { Legal environment of the construction land } \\
\text { reduction project }\end{array}$ & $\mathrm{C} 7$ & 3.448275424 & 3.448272553 & 6.896547977 & 0.000003 \\
\hline $\begin{array}{l}\text { Cultural environment of the construction land } \\
\text { reduction project }\end{array}$ & $\mathrm{C} 8$ & 2.516161824 & 2.515053676 & 5.0312155 & 0.001108 \\
\hline
\end{tabular}

\subsection{Analysis of model processing results and identification of key success factors}

KSFs of CLR projects refer to the key factors that make the project implement successfully in the preparation stage, decision-making stage, design stage, construction stage and post-management stage of CLR project. Identifying and concentrating these KSFs can make the project organizer pay attention to the important success factors in the project carefully, and give priority consideration in the process of organization and management, so that the project can meet the necessary conditions for completion. Paying attention to the KSFs can bring fruitful results and greatly improve effective completion of the project.

\subsubsection{Comprehensive influence degree calculation}

The FAHP method described in section 4.1 is used to calculate the corresponding weight of success factors of CLR projects, and the Fuzzy-DEMATEL method explained in section 4.2 is used to calculate the "cause degree $\mathrm{n}$, center degree $\mathrm{m}$ " of success factors. The weight corresponding to the factors is multiplied by the cause degree and center degree respectively to calculate the comprehensive cause degree and center degree of success factors of CLR projects. Tab.10 lists the 
comprehensive influence relationship among the $29 \mathrm{KSFs}$ of the CLR projects in detail.

$$
\begin{aligned}
& R_{i}=\omega_{i} * N_{i} \\
& \mathrm{O}_{i}=\omega_{i} * M_{i},
\end{aligned}
$$

\begin{tabular}{|c|c|c|c|c|c|c|}
\hline influence factor & $\begin{array}{l}\text { Factor } \\
\text { code }\end{array}$ & $\begin{array}{l}\text { Comprehensive } \\
\text { weight }\left(\omega_{i}\right)\end{array}$ & $\begin{array}{l}\text { Comprehensive } \\
\text { centrality } \\
\left(\mathrm{O}_{i}\right)\end{array}$ & $\begin{array}{l}\text { Comprehensive } \\
\text { centrality } \\
\text { ranking }\end{array}$ & $\begin{array}{l}\text { Comprehensive } \\
\text { cause degree } \\
\left(R_{i}\right)\end{array}$ & $\begin{array}{l}\text { Comprehensive } \\
\text { cause degree } \\
\text { ranking }\end{array}$ \\
\hline Development program & A1 & 0.099131656 & 0.86870026 & 1 & -0.0000039 & 23 \\
\hline Management system & $\mathrm{A} 2$ & 0.093383529 & 0.868572321 & 2 & -0.0000134 & 28 \\
\hline Cooperating agency & A3 & 0.076001998 & 0.571399553 & 3 & -0.0000067 & 26 \\
\hline Administrative regulation & A4 & 0.055057385 & 0.536573716 & 6 & -0.0000054 & 25 \\
\hline Quality certification & A5 & 0.044679784 & 0.335230153 & 9 & -0.0000005 & 14 \\
\hline $\begin{array}{c}\text { Diversity in the enterprises } \\
\text { participating }\end{array}$ & A6 & 0.025961061 & 0.225854086 & 13 & 0.0000003 & 7 \\
\hline Enterprise competence & A7 & 0.01904975 & 0.144530589 & 20 & -0.0000024 & 21 \\
\hline $\begin{array}{l}\text { Enterprise rules and } \\
\text { systems }\end{array}$ & A 8 & 0.000589332 & 0.003869266 & 29 & 0.0000000 & 9 \\
\hline $\begin{array}{l}\text { Coordination with the } \\
\text { original landowner }\end{array}$ & A9 & 0.04348909 & 0.306975737 & 11 & 0.0000071 & 2 \\
\hline $\begin{array}{l}\text { Coordination with the } \\
\text { surrounding local residents }\end{array}$ & A 10 & 0.047938739 & 0.295565847 & 12 & 0.0000004 & 6 \\
\hline Land beneficiary sector & A11 & 0.05529479 & 0.384899706 & 8 & -0.0000042 & 24 \\
\hline Construction progress & A 12 & 0.018931153 & 0.157646832 & 16 & -0.0000009 & 16 \\
\hline $\begin{array}{l}\text { Land acceptance and } \\
\text { testing standards }\end{array}$ & B1 & 0.016080984 & 0.127411562 & 21 & 0.0000023 & 5 \\
\hline Technology maturity & $\mathrm{B} 2$ & 0.012288772 & 0.103922238 & 23 & -0.0000005 & 15 \\
\hline Historical data & B3 & 0.01177725 & 0.077662602 & 24 & 0.0001181 & 1 \\
\hline Science of process & B4 & 0.017611569 & 0.147056371 & 19 & -0.0000014 & 19 \\
\hline Contract formulation level & B5 & -0.000662336 & -0.005132479 & 22 & -0.0000002 & 10 \\
\hline Land-use planning & B6 & -0.005426043 & -0.039830487 & 18 & -0.0002016 & 29 \\
\hline Administration Costs & B7 & -0.010189751 & -0.083478207 & 26 & -0.0000016 & 20 \\
\hline Cost of Capital & B8 & -0.014953458 & -0.130355674 & 25 & -0.0000014 & 18 \\
\hline $\begin{array}{c}\text { Richness of staff member } \\
\text { knowledge }\end{array}$ & B9 & -0.019717166 & -0.143806541 & 27 & -0.0000003 & 12 \\
\hline Supportive policies & $\mathrm{C} 1$ & -0.024480873 & -0.198235655 & 5 & 0.0000046 & 4 \\
\hline Leadership Decision & $\mathrm{C} 2$ & -0.029244581 & -0.222786593 & 7 & -0.0000004 & 13 \\
\hline System construction & $\mathrm{C} 3$ & -0.034008288 & -0.246633208 & 17 & -0.0000012 & 17 \\
\hline Coordination mechanism & $\mathrm{C} 4$ & -0.038771996 & -0.280750779 & 10 & -0.0000003 & 11 \\
\hline Fiscal Policy & $\mathrm{C} 5$ & -0.043535703 & -0.362994313 & 4 & -0.0000068 & 27 \\
\hline Land Policy & C6 & -0.04829941 & -0.368328604 & 14 & -0.0000032 & 22 \\
\hline
\end{tabular}

Table 10 Comprehensive influence relationship of success factors of construction land reduction 


\begin{tabular}{lllllll}
\hline Legal environment & C7 & -0.053063118 & -0.365952339 & 15 & 0.0000001 & 8 \\
Social environment & C8 & -0.057826825 & -0.29093922 & 28 & 0.0000065 & 3 \\
\hline
\end{tabular}

In this study, the weight of each factor is determined according to FAHP method, and then the mutual influence degree of each factor is determined by Fuzzy-DEMATEL method. The two methods combine the comprehensive cause degree and comprehensive center degree of the final factors. The comprehensive cause degree indicates the degree of correlation among the various $\mathrm{KSFs}$, which can be divided into cause factors (comprehensive cause degree $>0$ ) and result factors (comprehensive cause degree $<0$ ). The comprehensive centrality represents the importance of each factor in the whole factor system. Generally, the greater the value of comprehensive centrality, the more important this factor is. Combining the analysis of the two dimensions of comprehensive centrality and comprehensive cause, we can get KSFs of the CLR projects. With the comprehensive centrality as the horizontal axis and the comprehensive cause as the vertical axis, the Cartesian coordinate system is constructed. According to Tab. 10, the causal correlation diagram of the comprehensive influence relationship of the success factors is drawn as shown in Fig 4.

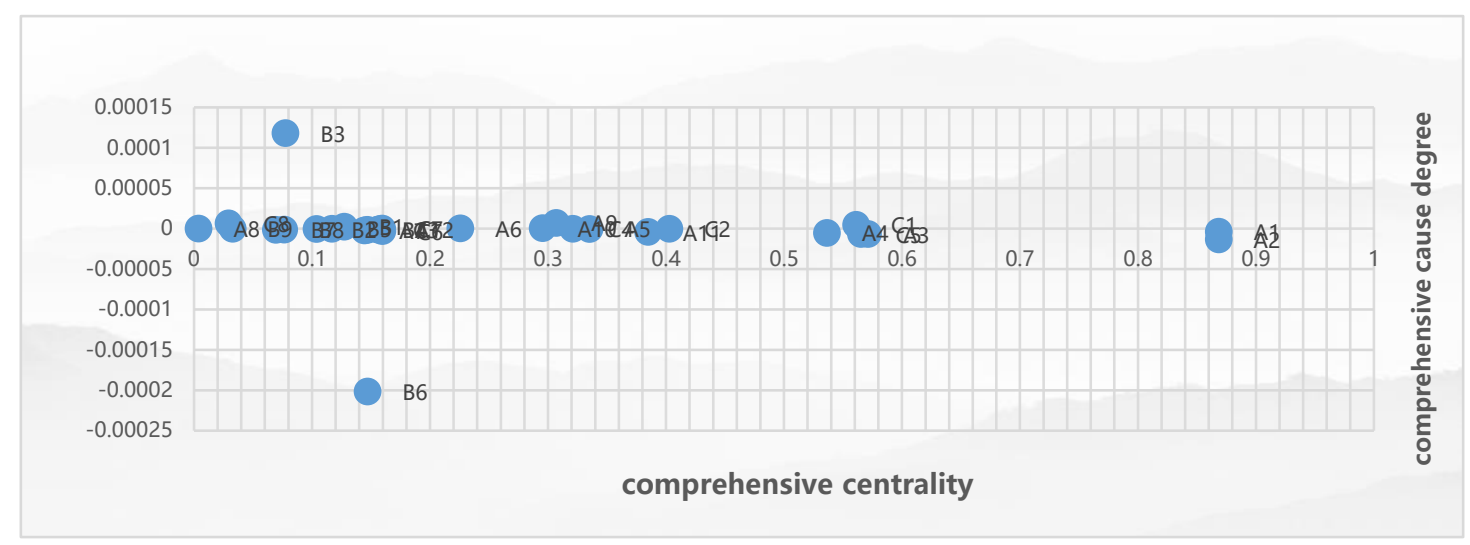

Figure 4 Comprehensive influence degree distribution map

Based on the data in Fig 4 and Tab. 10, the causes, dependence and comprehensive centrality are analyzed as follows.

\subsubsection{Identification of key success factors}

The identification principles of KSFs identification model for the CLR projects based on FAHP and Fuzzy-DEMATEL method are as follows:

(1) KSFs belong to the cause factor group whose comprehensive cause degree is greater than 0.

The comprehensive cause degree value of a factor represents the effect of this factor on other factors. If the comprehensive cause degree is $>0$, it shows that this factor has the characteristic of active influence on other factors in the system and is the cause factor; The comprehensive cause degree is less than 0 , which indicates that this factor has the influence on other factors in the system, that is, it is the result factor of the system. If a factor is the cause factor, it indicates that it will actively affect the operation of the whole system, so it is at the bottom of the factor ranking of the whole system. Therefore, if we want to find out KSFs of the CLR projects, we must start with the bottom factors, which are the root of the whole system operation.

(2) In the cause factor set, the success factor with large comprehensive centrality in the system is selected as the KSF. 
The greater the value of comprehensive centrality, the greater the comprehensive influence of this success factor on the system, indicating that this factor has a very important influence in the whole system. The factors in the cause factor set are sorted by comprehensive centrality, that is, the factors at the bottom of the whole system are judged by their influence degree. The higher the comprehensive centrality, the higher the ranking, the higher the influence degree of the bottom factors on the whole system. Shown in Fig 5.

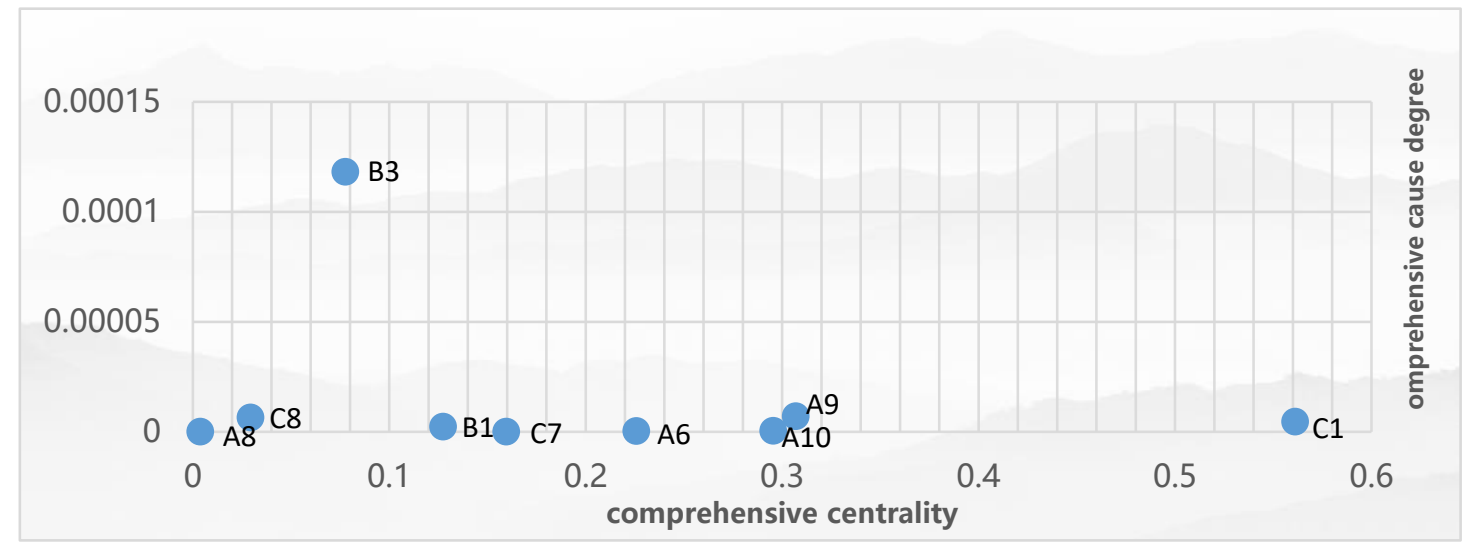

Figure $5 \mathrm{KSF}$ s Comprehensive influence degree distribution map

(3) According to the Pareto rule in the field of management, the top $20 \%$ factors are selected as KSFs.

Pareto rule, that is, the 28-effect, means that in any specific group, important factors usually account for only a few, so long as a few important factors can be controlled, the whole situation can be controlled. Therefore, in the success factor system, it is sufficient to select about $20 \%$ of the factors as KSFs.

Based on the principle of data analysis and identification of KSFs, the identification results are as follows;

(1) It can be known from Tab. 10 and causality diagram that the cause factors include the following nine factors: $\mathrm{B}_{3}$ Historical data, $\mathrm{A}_{9}$ Coordination with the original landowner, $\mathrm{C}_{8}$ Social environment, $\mathrm{C}_{1}$ Supportive policies, $\mathrm{B}_{1}$ Land acceptance and testing standards, $\mathrm{A}_{10}$ Coordination with the surrounding local residents, $A_{6}$ Diversity of participating enterprises, $C_{7}$ Legal environment, $A_{8}$ Enterprise rules and systems.

(2) According to the comprehensive centrality ranking of 9 factors, the order of influence degree can be obtained as follows: $C_{1}>A_{9}>A_{10}>A_{6}>C_{7}>B_{1}>B_{3}>C_{8}>A_{8}$ 。

(3) Based on Pareto rule, because there are 29 factors affecting the success of CRL projects, $20 \%$ of them are selected as KSFs, which include six success factors. According to the comprehensive centrality of the cause factors, the top six are $C_{1}, A_{9}, A_{10}, A_{6}, C_{7}$ and $B_{1}$. Therefore, the key success factors of the construction land reduction project are: $\mathrm{C}_{1}$ supportive policies, $A_{9}$ coordination with the original landowner, $A_{10}$ coordination with the surrounding local residents, $A_{6}$ diversity in the enterprises participating, $C_{7}$ legal environment, $B_{1}$ land acceptance and testing standards.

\section{Key success factors interpretation}

Three key success factors for construction land reduction include coordination with the original landowner, coordination with the surrounding local residents and a diversity in the 


\section{enterprises participating in the construction land reduction.}

Implementing CLR projects successfully can maintain the total area of construction lands while achieving an optimised layout, improved functions and more intensive land use. However, it is necessary to address many problems that arise with the local residents and regional economic development. A local economy can undergo a continuous evolution from the enterprises of the original village, to those of a township, to an industrial park. Today, although many employment opportunities are provided by industrial enterprises in the scope of a 'reduction' project, many enterprises must close down increase the adoption of CLR, which results in high unemployment and an increasing range of social problems.

Although the government has devoted significant attention to the 'land reduction' activities, however, effective guidance and support are lacking for the subsequent operation of enterprises. As a result, many enterprises are no longer enthusiastic regarding 'second entrepreneurship and retransformation' because of the lack of government compensation for land reduction and demolition, let alone the related social costs. For example, with over 200 employees and annual sales of CNY 100 million, the Junchen and Dongsheng Industry in the town of Heqing, which distributes international brands, was forced to close down after 'reduction' work and demolition because of its lack of appropriate workshop, which resulted in the loss of employment for all staff and losses in finance and taxation. Therefore, this reduction seriously influenced the livelihood of local residents and the regional economic development.

When the concept of 'land reduction' was proposed, the public generally considered it to mean a reduction in quantity of both inventory land (current status) and new land (planning). However, CLR was found to decrease the assets of original landowners and the available benefits associated with the original lands of the local residents. To address this situation, the key is to reduce the lands in the process of 'reduction' and not the benefits associated with them for the original landowners and surrounding residents. That is, with decreases in the scale of land use or improvement in land use efficiency, the benefits of the lands enjoyed by the original landowners and other interested parties cannot be decreased.

Moreover, China's land testing and reclamation institutions must solve many problems, of which the large number of institutions, their small scale, fierce competition, low competitive power, weakness and weak international competition are the most salient. Hence, it is necessary to provide policy guidance to create an environment characterised by fair competition and advanced management practices to ensure sound land development.

As such, another KSF for CLR is the establishment of land acceptance and testing standards.

Optimisation of the spatial layout of ecological and construction lands is a key factor in coordinating economic development and ecologically sustainable construction practices. In CLR projects, some construction land is reclaimed as arable land, thus increasing the ecological land area. In addition, the ecological quality of land is improved by improving the quality of arable lands and the reclamation of forest lands.

However, in CLR project in the Qingpu District (Shanghai), the quality of the reclaimed lands after reduction was different and crops were not planted on some of these lands. The thickness and looseness of the reclaimed land layer, the support facilities, and the soil and underground water 
quality must be strictly managed in accordance with planting standards because these lands were construction lands before the reclamation, which means most may have been industrial lands that have been polluted. Lack of qualified personnel to perform land inspections and testing will negatively impact the ecological environment and can even result in the waste of land resources, and also threatening the health and safety of the surrounding residents. Therefore, the establishment of comprehensive land acceptance and testing standards is crucial for the effectiveness of a 'reduction' project.

The KSF of CLR with respect to institutions and the environment include supportive policies and the establishment of a legal environment.

In the initial stage of the 'reduction' work, the public had not completely understood or participated in the 'reduction' work, so the government has had the dominant role in advancing and regulating the 'reduction' process. In the new policy, CLR involves different governmental levels and sectors. In the initial stage of a project, the government must define the responsibilities and procedures to be followed by these sectors. In addition, due to the lack of experience in performing CLR, the distribution of benefits may have been unfair, whereby enterprises and residents that have been affected did not obtain sufficient compensation, which must be resolved by the government. As the manager of social conflicts, the government must play the dominant role in establishing an overall plan for the 'reduction' work that is comprehensive and ensures sufficient improvement in social, economic, and ecological factors through this 'reduction'. Today, the existing inventory of construction lands includes both legal and illegal construction lands. It would be inappropriate to strengthen the benefits of legal lands only while ignoring illegal construction lands. Therefore, dealing with historical problems appropriately and creating a sound legal environment is crucial for effective construction land reduction.

\section{Conclusion}

Construction Land Reduction (CLR) is a strategy to improve the intensive use of land and control the unlimited expansion, also to ensure the balance between the occupation and compensation of construction land and cultivated land in China. To use construction land effectively is a huge dilemma in developing economies and a complex process which is influenced by many factors. The crucial aspect of this process is the determination of key success factors (KSFs). In this study, we focused on the current development status of CLR projects and performed a literature review, conducted an expert investigation, used questionnaires and the FAHP \& Fuzzy-DEMATEL methods, in order to identify major KSFs for the projects.

The results demonstrate that supportive policies, coordination with the original landowner, coordination with the surrounding residents, a diversity of enterprises participating in the project, a legal environment and the establishment of land acceptance and testing standards are the KSFs. These factors are of utmost importance, and if considered and implemented while working for any CLR, it will improve the overall working of the project. The outcomes and findings of the paper will be helpful in decision - making process for the smooth performance of the project, the government and its functional departments can use the research results to design corresponding policies and systems. Under this premise, all parties can effectively participate in the CLR project, promote the social and economic sustainable development goals. 
This study may has some limitations. It established an FAHP model with 29 success factors to CLR identified through literature review and screened by expert opinion. Future research may consider other essential success factors according to their context. This study is also based on empirical data from Chinese experts only. However, these results can be generalized to similar economies.

\section{Competing Interests}

Not applicable

\section{Ethical Approval}

The authors declare that they have no conflict of interest.

\section{Consent to Participate}

The experimental protocol was established, written informed consent was obtained from individual or guardian participants.

\section{Consent for publication}

Written informed consent for publication was obtained from all participants.

\section{Authors Contributions}

Dr.Qiang Li contributed to the conception of the study;

Prof.Lifang Wang performed the experiment;

Prof.Yuming Zhu contributed significantly to analysis and manuscript preparation;

Dr.Bingxu Mu performed the data analyses and wrote the manuscript;

Dr.Naveed Ahmad helped perform the analysis with constructive discussions.

\section{Availability of data and materials}

All data generated or analysed during this study are included in this published article.

\section{Funding}

This study had no financial support

\section{References:}

Bin Wang\& Zhang Zigang. "The cooperation model on innovation activity between supply chain enterprises based on Pareto Principle [J]." Science Research Management 2 (2003).

Chi Zhang. The Effect Analysis of the reduction of Newly Increased Area on the Municipal Investment Bonds: Evidence from the cities in China[D].Nanjing university,2019.

Government Work Report. http://www.mnr.gov.cn/dt/ywbb/202005/t20200522_2516477.html the website of the Central People's Government of the PRC 2020-05-22

Gu XK ,L, DAI B. Suitability assessment of reducing industrial land in Shanghai metropolitan region[J]. Journal of Natural Resources, 2018, 33(8): 1317-1325.

Hai Jiang,Tu Lv.Research on the "Three Fitness" Principle in the Reduction of Construction Land[J].Natural Resource Economics of China,2016,29(06):15-17+64.

Hongmei L, Peng M, Kexing M. Study on reduction of construction land in the developed area: reviews of the workshop on'land use pattern changing and construction land reduction the New Normal'[J]. China Land Science, 2015, 29(12): 11-17.

Ju Yingyan. Study on construction land reduction based on smart shrinkage[D].Nanjing Normal University. 
Juan Huang.Reflections on Rural Revitalization in Shanghai from the Perspective of Planned Land Management -- A Case Study of Songjiang District[J].Shanghai Rural Economics,2020(05):13-16. Li Tian,Xu Guo,Wei Yin. From urban sprawl to land consolidation in suburban Shanghai under the backdrop of increasing versus decreasing balance policy: A perspective of property rights transfer[J]. Urban Studies, 2017,54(4).

Ming Chen.Land use pattern optimization under the scenarios of construction land with SU XI CHANG area, from the perspective of the little egret's habitat network conservation and optimization[D].Nanjing Agricultural University,2017.

Outline of the 13th Five-Year Plan.http://www.gov.cn

Rockart, J.F. (1979) Chief Executives Define Their Own Data Needs. Harvard Business Review, 57, 81-93.

Shaoqin Zhuang. A new type of land consolidation is boosting the development of a new type of urbanization[J].China Land,2015(09):10-12.

Shoubo Gu,Wei Liu,Qing Xia.Creating a New Pattern of "Land Consolidation +" -- Shanghai's Innovation and Practice[J].China Land,2016(09):42-44.

Shoubo Gu. The policy design and exploration of construction land reduction in "198" area of Shanghai[J].China Land. 2015,(11)

Shuang Li,Jiang Lou. The way of land ownership adjustment for the reduction of state-owned construction land: a case study of Shanghai[J].China Land,2016(10):38-39.

Tao, Cao KangJin. "A Discussion on Brownfield Redevelopment Strategies in Western Countries and Its Inspiration to China [J]." China Population Resources and Environment 6 (2007).

Xiaojie Zhang, Zixiao Liu. Tianjin construction land reduction policy implementation problems[J].China Land. 2018,(12).

Xiaokun Gu,Jing Liu,Bin Dai,Duo Chai.Suitability Assessment of Reducing Industrial Land in Shanghai Metropolitan Region[J]. Journal of Natural Resources, 2018, 33(08):1317-1325.

$\mathrm{Xu}$ Guo. Governance of stock construction land in the background of land consolidation in the developed regions: a new analytical framework of spatial governance[J].City Planning Review,2020,44(01),52-62

Yi Ding. Transactions of the Chinese Society of Agricultural Engineering Identification and redevelopment strategy of underused urban land in underdeveloped countries using system theory[J]. 2020,36(14),316-326

Yu He.Problems and countermeasures of land consolidation project management[J].China Southern Agricultural Machinery,2019,50(15):266+270.

Yu Ming-Jie, Peng Guo, and Yuming Zhu. "Research on Combination Evaluation of Brownfield Redevelopment Project Based on Method Set [J]." Operations Research and Management Science 3 (2011).

YuanQing Wu. Comparison of Shanghai country unit planning modes[J].Shanghai Land \& Resources,2015,36(02):28-32.

Yuming Zhu, Qingfen L, Haitang S, et al. SEM-Based Optimization of Evaluation Index System for Brownfield Redevelopment[J]. Industrial Engineering Journal, 2011, 14(6): 65. 
Yuming, Zhu. "Comparison Study on Policies and Regulations of Brownfields Cleanup and Redevelopment at Home and Abroad [J]." Environmental Protection Science 3 (2009).

Zhengfeng Zhang,Jing Liu,Xiaokun Gu. Reduction of industrial land beyond Urban Development Boundary in Shanghai: Differences in policy responses and impact on towns and villages[J]. Land Use Policy,2019,82. 


\section{Figures}

\section{Identification of KSFs from literature}

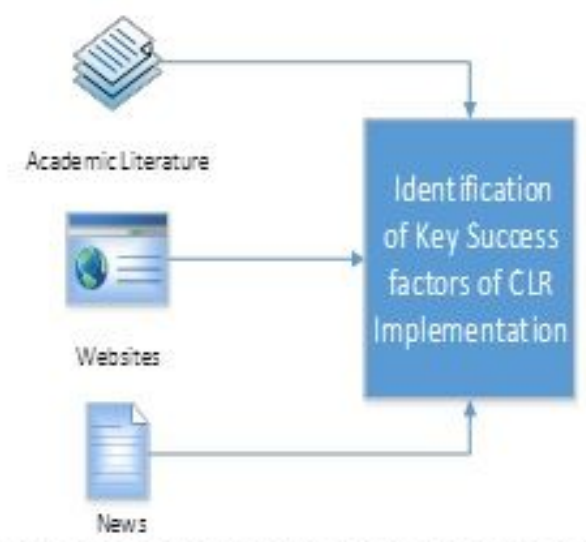

3. Evaluation of cause and effect relationship

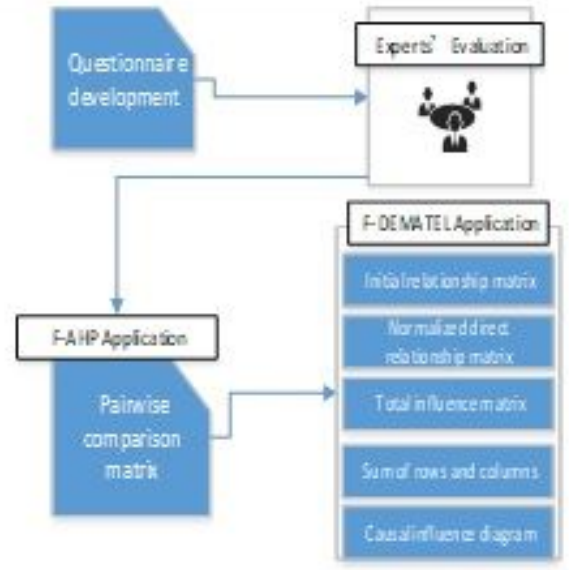

\section{Consensus on KSFs by experts}
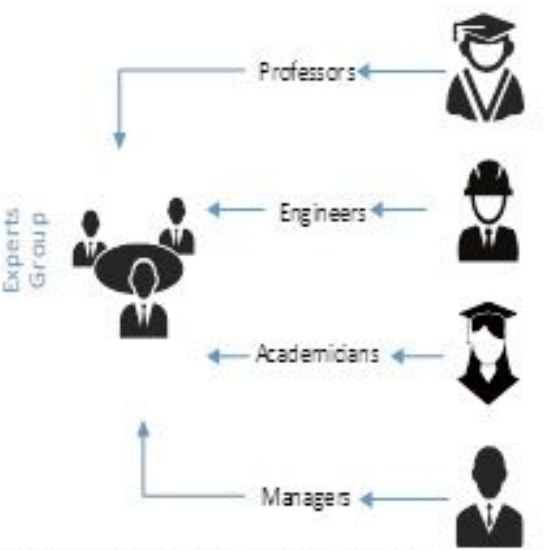

4. Validation of results

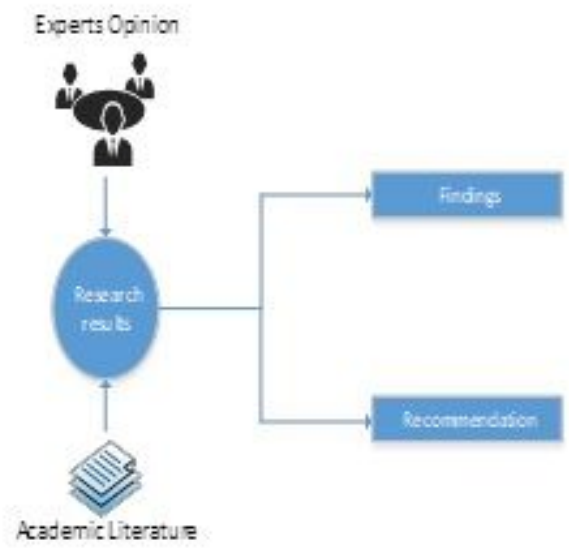

Figure 1

Proposed framework of study

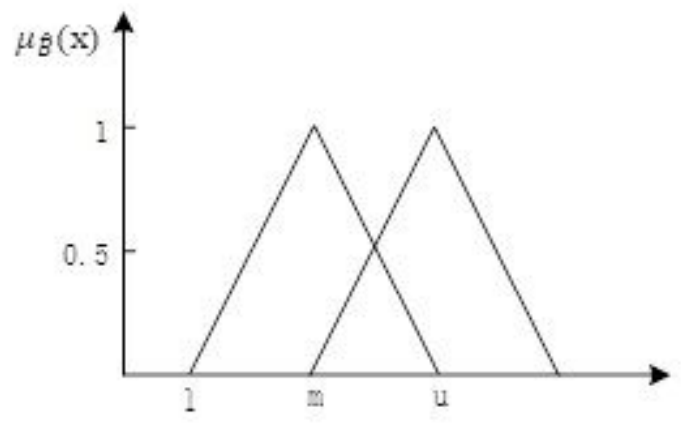

Figure 2

Triangular fuzzy correspondence diagram 


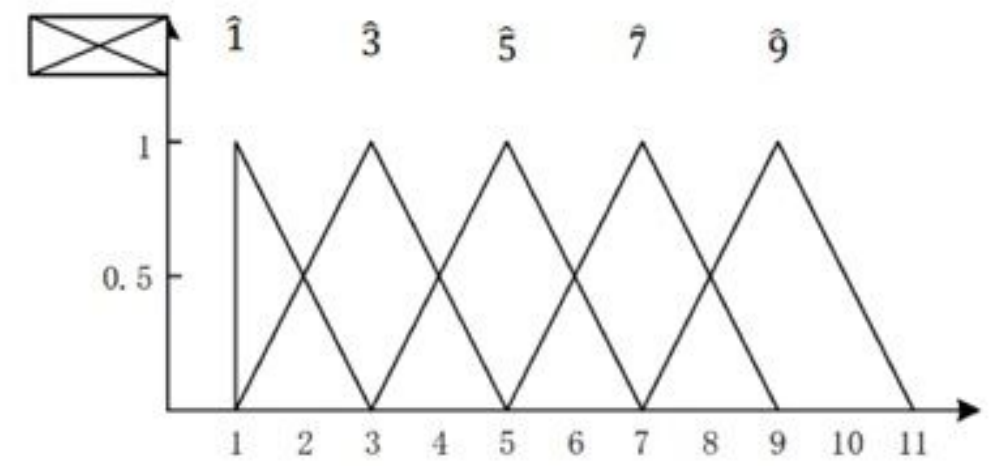

Figure 3

Transforming the determined value into triangular fuzzy number

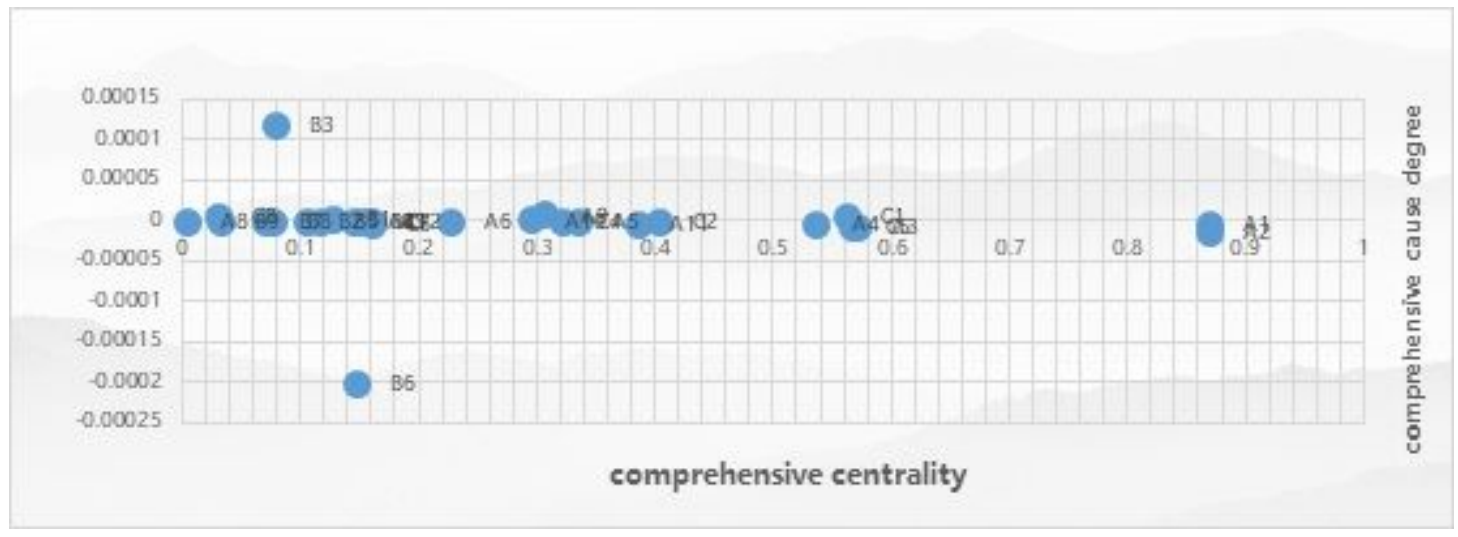

\section{Figure 4}

Comprehensive influence degree distribution map

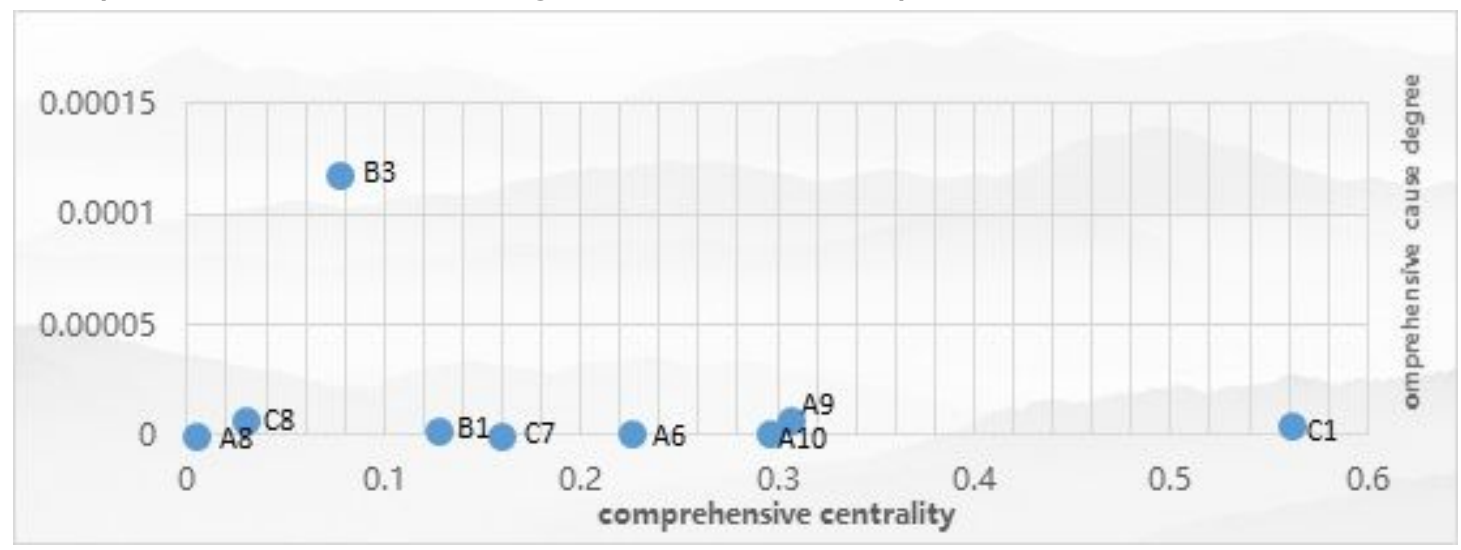

Figure 5

5 KSFs Comprehensive influence degree distribution map 